\title{
A long-term study of stable isotopes as tracers of processes governing water flow and quality in a lowland river basin: the upper Thames, UK
}

\author{
W George Darling ${ }^{1 *}$ and Michael J Bowes ${ }^{2}$ \\ ${ }^{1}$ British Geological Survey, Wallingford OX10 8BB, UK \\ ${ }^{2}$ Centre for Ecology and Hydrology, Wallingford OX10 8BB, UK
}

\begin{abstract}
A long-term study of $\mathrm{O}, \mathrm{H}$ and $\mathrm{C}$ stable isotopes has been undertaken on river waters across the $7000 \mathrm{~km}^{2}$ upper Thames lowland river basin in the southern UK. During the period, flow conditions ranged from drought to flood. A 10-year monthly record (2003-2012) of the main River Thames showed a maximum variation of $3 \%\left(\delta^{18} \mathrm{O}\right)$ and $20 \%\left(\delta^{2} \mathrm{H}\right)$, though inter-annual average values varied little around a mean of $-6.5 \%$ o $\left(\delta^{18} \mathrm{O}\right)$ and $-44 \%$ o $\left(\delta^{2} \mathrm{H}\right)$. The $\delta^{2} \mathrm{H} / \delta^{18} \mathrm{O}$ slope of 5.3 suggested a degree of evaporative enrichment, consistent with derivation from local rainfall with a weighted mean of $-7.2 \% 0\left(\delta^{18} \mathrm{O}\right)$ and $-48 \%$ o $\left(\delta^{2} \mathrm{H}\right)$ for the period. A tendency towards isotopic depletion of the river with increasing flowrate was noted, but at very high flows $\left(>100 \mathrm{~m}^{3} / \mathrm{s}\right)$ a reversion to the mean was interpreted as the displacement of bank storage by rising groundwater levels (corroborated by measurements of specific electrical conductivity). A shorter quarterly study (October 2011 - April 2013) of isotope variations in 15 tributaries with varying geology revealed different responses to evaporation, with a high inverse correlation between $\Delta^{18} \mathrm{O}$ and baseflow index (BFI) for most of the rivers. A comparison with aquifer waters in the basin showed that even at low flow, rivers rarely consist solely of isotopically unmodified groundwater.

Long-term monitoring (2003-2007) of carbon stable isotopes in dissolved inorganic carbon (DIC) in the Thames revealed a complex interplay between respiration, photosynthesis and evasion, but with a mean inter-annual $\delta^{13} \mathrm{C}$-DIC value of $-14.8 \pm 0.5 \%$, exchange with atmospheric carbon could be ruled out. Quarterly monitoring of the tributaries (October 2011 - April 2013) indicated that in addition to the above factors, river flow variations and catchment characteristics were likely to affect $\delta^{13} \mathrm{C}$-DIC. Comparison with basin groundwaters of different alkalinity and $\delta^{13} \mathrm{C}$-DIC values showed that the origin of river baseflow is usually obscured.

The findings show how long-term monitoring of environmental tracers can help to improve the understanding of how lowland river catchments function.
\end{abstract}

KEY WORDS Stable isotopes; baseflow index; dissolved inorganic carbon; groundwater; rainfall; river response; specific electrical conductivity

\section{INTRODUCTION}

The use of $\mathrm{O}, \mathrm{H}$ and $\mathrm{C}$ stable isotopes applied to river catchment studies has a long pedigree (Kendall and McDonnell, 1998). An outstanding early success using $\delta^{18} \mathrm{O}$ was the discovery

*Correspondence to: W George Darling, British Geological Survey, Maclean Building, Wallingford, OX10 8BB, UK. E-mail: wgd@bgs.ac.uk 
that much so-called 'event water' in streams was not in fact derived from recent rainfall, but instead consisted of water displaced from soil storage (Sklash and Farvolden, 1979). Further insights from $\delta^{18} \mathrm{O}$ and/or $\delta^{2} \mathrm{H}$ included the calculation of mean water residence times, identifying flow sources and flowpaths, and recognition of evaporative fractionation (e.g. Stewart and McDonnell, 1991; Hogan and Blum, 2003; Burns and McDonnell, 1998), and the field continues to progress (McGuire an McDonnell, 2015). Many of these studies were carried out on relatively small test catchments no more than a few tens of $\mathrm{km}^{2}$ in area and often with steep gradients and therefore hydraulic heads. In parallel with these small catchment studies, some large river systems covering a range of topographies were investigated using stable isotopes (e.g. Ramesh and Sarin, 1992; Cameron et al., 1995; Pawellek et al., 2002) but not in the same detail as the small systems for obvious logistical reasons. The same situation was largely the case for $\delta^{13} \mathrm{C}$ in the dissolved inorganic carbon (DIC) system: small scale (e.g. Amiotte-Suchet et al., 1999) versus large scale (e.g. Aucour et al., 1999).

Since those earlier studies demonstrating the value of stable isotopes as environmental tracers, their use has become a standard technique to gain more knowledge of catchment processes (Schulte et al., 2011). Increasingly, too, mesoscale catchments are being investigated (e.g. Ogrinc et al., 2008; Speed et al., 2010; van Geldern et al., 2015). Yet the isotope records from these tend to be limited in scope and duration because of resource constraints, and therefore provide only a partial view into catchment processes. In particular, there has been little investigation of rivers on the multi-year scale (Halder et al., 2015), which has meant there is limited knowledge of how isotopic responses vary over a range of flow conditions. Long-term monitoring of the River Thames and its upper tributaries has provided an opportunity to do this in a mesoscale catchment with varied geology. Specific areas of interest were variations due to evaporation, response over drought to flood conditions, relationship to baseflow index, and river-groundwater interaction (using $\delta^{18} \mathrm{O}$ and $\delta^{2} \mathrm{H}$ ), and characterising the dissolved inorganic carbon baseline (using $\delta^{13} \mathrm{C}$-DIC). A subsidiary aim was to compare the merits of isotopic tracers against those of the simple tracer SEC (specific electrical conductivity) in a lowland river basin.

In addition to contributing to a better understanding of catchment functioning, the stable isotope baseline for the upper Thames basin established by this study is likely to inform fields such as archaeology, ecology and palaeoenvironmental studies (previous examples from the 
area include Candy et al., 2007; Hughes et al., 2014; Keatings et al., 2002; Versteegh et al., 2013).

\section{STUDY AREA AND METHODS}

\section{Study area}

The study area covers about $7000 \mathrm{~km}^{2}$ of the western Thames basin (Fig. 1). It extends from the perennial headwaters in the Cotswold Hills to Runnymede, some $200 \mathrm{~km}$ downstream of the river's source but lying above the major river water intakes (abstracting up to 50\% of flow) which serve the population of Greater London. From the source to Runnymede amounts to approximately $85 \%$ of the length of the non-tidal portion of the Thames, which ends a further $30 \mathrm{~km}$ downstream at Teddington Weir in the SW of the Greater London area.

River gradients within the basin are generally very low: for example, the main Thames falls only some $60 \mathrm{~m}$ between Cricklade and Runnymede (Fig 1).

2011 Census figures indicate that the area drained by the upper Thames contains of the order of $2 \mathrm{M}$ people. This, combined with a comparatively low average annual rainfall of $\sim 690 \mathrm{~mm} / \mathrm{yr}$ and an estimated potential evapotranspiration rate of $\sim 580 \mathrm{~mm} / \mathrm{yr}$ (Jolley and Wheater, 2007), means that the area is prone to drought, thus making highly desirable any additional information relevant to water resource management.

\section{Hydrogeology}

The geology of the upper Thames basin (Fig. 1) consists of Mesozoic and Cenozoic sedimentary rocks with a regional dip towards the SE. The NW of the area is dominated by Lower, Middle and Upper Jurassic rocks, mainly oolitic limestones and clays, from which rise all the significant tributaries upstream of Wallingford. Downstream of this point, the Thames flows over Chalk strata (Upper Cretaceous) until the river runs onto the Palaeogene at Maidenhead. Between Wallingford and Runnymede the main tributaries are mostly on the southern bank and may derive wholly from the Chalk or Palaeogene, or a mixture of both. 
The flow direction of rivers and streams in the upper basin is largely controlled by geological structure.

Within the upper Thames basin, the Jurassic Oolite and Cretaceous Chalk tend to be productive aquifers. The Jurassic and Palaeogene clays on the other hand have limited aquifer properties, often functioning largely as aquicludes. The consequence of this is that the rivers arising from the different strata have proportionately different inputs of groundwater. In the case of short streams fed predominantly by limestone or Chalk, e.g. the Coln and Pang, nearly all their flow consists of groundwater. At the other extreme, for clay vale rivers like the Ray and The Cut, less than half their mean flow derives from groundwater. For each of the tributaries, the groundwater contribution can be relatively quantified in terms of the Baseflow Index (BFI), which is based on hydrograph separation techniques (Marsh and Hannaford, 2008). Table 1 reports these together with mean river flows based on gauging records obtained from the UK Environment Agency (EA). Also included are a series of BFI and flow values for gauging points along the Thames.

The relationship between geology and hydrology across the Thames basin is examined in greater detail in Andrews (1962) and Bloomfield et al. (2011).

\section{Datasets acquired}

At the core of the present study is a 10-year monthly record of $\delta^{18} \mathrm{O}, \delta^{2} \mathrm{H}$ and a 5-year record of $\delta^{13} \mathrm{C}$-DIC (dissolved inorganic carbon) collected from the Thames at Wallingford, Oxfordshire, effectively the outlet point for river discharge from the predominantly Jurassic strata (mainly limestones and clays) of the upper part of the upper Thames basin (Fig. 1). This is supplemented by a quarterly record of $\delta^{18} \mathrm{O}, \delta^{2} \mathrm{H}$ and $\delta^{13} \mathrm{C}$-DIC variations at various points along a $175 \mathrm{~km}$ length of the river and from 15 tributaries, carried out over the course of a 18-month period which proceeded from drought to flood conditions. The data are completed by a 1 -year monthly $\delta^{18} \mathrm{O}, \delta^{2} \mathrm{H}$ record from two sites covering the reach where the Thames crosses the Chalk (a source of groundwater discharge to the river), an 18-month record of $\delta^{18} \mathrm{O}, \delta^{2} \mathrm{H}$ and $\delta^{13} \mathrm{C}$-DIC from the foot of the study area at Runnymede, and a 22month record of $\delta^{18} \mathrm{O}, \delta^{2} \mathrm{H}$ and $\delta^{13} \mathrm{C}$-DIC from the River Thame, which has the lowest BFI of any of the more significant upper Thames tributaries (rivers with a mean flowrate $\geq 3 \mathrm{~m}^{3} / \mathrm{s}$, Table 1). 
Any consideration of isotopes in the upper Thames basin also requires a record of the rainfall input to the catchment. Monthly precipitation samples have been collected at Wallingford for isotope analysis since 1983 (Darling and Talbot, 2003; the IAEA-WMO WISER database (https://nucleus.iaea.org/wiser)), and this collection continued throughout the monitoring period.

Site selection, sampling and analysis

Locations of all sampling points referred to in this study are shown on the map in Fig. 1. Sampling points were usually selected to be as close as practicable to the foot of each tributary's catchment bearing in mind that repeat visits would be necessary (hence, for example, the Cherwell was sampled upstream of the suburbs of Oxford. Proximity to a gauging point was also a consideration for rivers like the Thame, which is gauged well above its confluence with the Thames. Thames sampling sites were chosen to be roughly equidistant down the river. In all cases care was taken to collect samples from the freeflowing river rather than shallow areas or backwaters. For the long-term Thames monitoring, samples of river water were collected at Wallingford Bridge on the final day of each calendar month. Separate samples were taken in glass bottles for $\delta^{18} \mathrm{O} / \delta^{2} \mathrm{H}(28 \mathrm{~mL})$ and $\delta^{13} \mathrm{C}$-DIC $(60 \mathrm{~mL})$. Standard analytical methods were used $\left(\mathrm{CO}_{2}\right.$ equilibration for $\delta^{18} \mathrm{O}$, zinc reduction for $\delta^{2} \mathrm{H}$, acidification for $\delta^{13} \mathrm{C}$-DIC, followed by IRMS measurement on a VG-Optima mass spectrometer). Results are expressed in permil (\%) with respect to VSMOW (for $\delta^{18} \mathrm{O}$ and $\delta^{2} \mathrm{H}$ ) and VPDB (for $\delta^{13} \mathrm{C}$-DIC). Analytical precisions were $\pm 0.1 \%$ o $\left(\delta^{18} \mathrm{O}\right), \pm 1 \%$ ( $\left(\delta^{2} \mathrm{H}\right)$ and $\pm 0.2 \%$ o $\left(\delta^{13} \mathrm{C}\right.$-DIC). Specific electrical conductivity (SEC, referenced to $25^{\circ} \mathrm{C}$ ) and $\mathrm{pH}$ alkalinity were measured in the laboratory at BGS Wallingford.

A similar analytical process was applied to the shorter set of monthly samples collected from the River Thame at Dorchester and from the Thames at Runnymede. For the set of tributary samples collected quarterly, details of sampling locations are contained in Table 1. SEC and pH-alkalinity were measured in the Wallingford laboratories of BGS and CEH respectively. $\mathrm{O}, \mathrm{H}$ and $\mathrm{C}$ stable isotopes were determined as above at BGS Wallingford until June 2012 and at BGS Keyworth (NIGL) thereafter. 
Monthly rainfall samples were collected on the final day of each calendar month from the CEH Wallingford met site. Samples were measured for $\delta^{18} \mathrm{O}$ and $\delta^{2} \mathrm{H}$ using the analytical methods outlined above.

All the data are reported in the supplementary tables S1 to S6 (see Supporting Information).

\section{RESULTS AND DISCUSSION}

\section{Rainfall-river relationship}

The term 'rainfall' as used here includes precipitation falling as snow (a very low proportion of the total). Results of rainfall analysis from January 2003 to May 2013 are given in Table S1. A $\delta$-plot (Fig. 2) for the ten years 2003-2012 shows a very wide range of compositions $\left(\sim 13 \%\right.$ in $\delta^{18} \mathrm{O}, \sim 105 \%$ in $\left.\delta^{2} \mathrm{H}\right)$ defining a meteoric line with the form

$$
\delta^{2} \mathrm{H}=7.45 \delta^{18} \mathrm{O}+5.87 \quad\left(\mathrm{n}=119, \mathrm{r}^{2}=0.96\right)
$$

which is, as would be expected for a temperate climate, close to the form of the Global Meteoric Water Line (GMWL) of Craig (1961):

$$
\delta^{2} \mathrm{H}=8 \delta^{18} \mathrm{O}+10
$$

Values of $\delta^{18} \mathrm{O}$ and $\delta^{2} \mathrm{H}$ are highly correlated. The amount-weighted mean of rainfall over the years $2003-2012$ is $-7.22 \% \delta^{18} \mathrm{O}$ and $-47.9 \% \delta^{2} \mathrm{H}$, very similar to the mean for the previous 20 years $(-7.25 \%$ and $-50.0 \%$ respectively; Darling and Talbot, 2003). Yearly amounts ranged from $435 \mathrm{~mm}$ in 2011 to $797 \mathrm{~mm}$ in 2012, coincidentally juxtaposing two years of very different rainfall input towards the end of the long-term monitoring period at Wallingford and during the quarterly monitoring of the tributaries. Indeed the whole period 2003-2012 was notably volatile in annual rainfall amount, though the decadal mean was only $\sim 4 \%$ below the $20^{\text {th }}$ Century average (T.J. Marsh, pers. commun.). 
The strong correlation between $\delta^{18} \mathrm{O}$ and $\delta^{2} \mathrm{H}$ means that trends over time need be considered for one isotope only. For this study, $\delta^{18} \mathrm{O}$ will be used ( $\left(\delta^{18} \mathrm{O}_{\mathrm{p}}\right.$ '). Fig. 3a depicts inter-annual statistics which show that despite large annual ranges, mean $\delta^{18} \mathrm{O}_{\mathrm{p}}$ values vary rather little. There is an inverse correlation with rainfall amount $\left(r^{2}=0.52\right)$.

Figure $3 \mathrm{~b}$ shows the seasonal rainfall statistics. The mean values show the expected cyclic structure typical of annual rainfall over much of the world (Rozanski et al., 1993), though the isotopic enrichment of the summer half-year is less well defined than the depletion of the winter half-year. Overall there is no correlation with rainfall amount $\left(\mathrm{r}^{2}=0.00\right)$, though this conceals a highly-developed inverse trend for the months of April-August $\left(r^{2}=0.92\right)$, also noted for the previous 20 years in Darling and Talbot (2003). This presumably reflects the continuing dominance over the summer half-year of convective rainfall, which is more likely than frontal rainfall to give rise to the 'amount effect' on isotope ratios (Dansgaard, 1964).

Thames-Wallingford results are reported in Table S2. On a $\delta$-plot with the rainfall data for comparison it is apparent that the river has a restricted range but still varies by some $3 \%$ in $\delta^{18} \mathrm{O}$ and $20 \%$ in $\delta^{2} \mathrm{H}$ (Fig. 2). The data give a regression line of the form

$$
\delta^{2} \mathrm{H}=5.33 \delta^{18} \mathrm{O}-8.92 \quad\left(\mathrm{n}=120, \mathrm{r}^{2}=0.74\right)
$$

which possesses a slope characteristic of surface water evaporation at a relative humidity of $\sim 77 \%$ (Clark and Fritz, 1997), a value lying within the long-term mean for the Thames basin of $76-82 \%$ (Jenkins et al., 2009). There is however a tendency for the slope to vary seasonally, with the 8 out of 12 months which have good inter-annual correlations $\left(r^{2}>0.75\right)$ revealing slopes ranging progressively from 5.1 in the summer to 8.0 in winter. This would be consistent with observations of seasonal changes in slope noted for other rivers (e.g. Kendall and Coplen, 2001)

The mean isotopic composition of the river water samples is $-6.51 \%$ and $-43.6 \% \delta^{2} \mathrm{H}$. This is slightly isotopically enriched compared to the rainfall weighted mean. (While rainfall is only monitored at one site, i.e. Wallingford, this lies approximately at the centre of the upper Thames basin and therefore should be reasonably representative of conditions across the study area, bearing in mind the subdued relief of the catchment.) The difference between the river and rainfall averages is further evidence for a small degree of evaporative enrichment in 
the river water, particularly in the summer. In this connection it may be noted that while the Thames is free of water impoundments or low-flow augmentation, the river does have flowlimiting weir/lock combinations on average every $4.6 \mathrm{~km}$, and there may also be limited interaction between the river and flooded former gravel extraction pits in its floodplain.

\section{River flow conditions}

Stable isotopes As with rainfall, the good overall $\delta^{18} \mathrm{O}-\delta^{2} \mathrm{H}$ correlation for river water allows the use of a single isotope, in this case ' $\delta{ }^{18} \mathrm{O}_{\mathrm{r}}$ ', when considering processes other than evaporation. Examination of the Thames-Wallingford data in Table S2 shows that the interannual mean values vary little, with $\delta^{18} \mathrm{O}_{\mathrm{r}}$ in a narrow band of $\pm 0.3 \%$ about a value of $-6.5 \%$ (Fig. 3c). However, overall ranges can vary by a factor of two, from $1.3 \%$ in 2007 and 2012 to $2.6 \%$ in 2003 (values typical of mid-latitude rivers irrespective of catchment size or river length: Halder et al., 2015). Seasonally, mean values show the river reaching a maximum depletion in February and December, and maximum enrichment in August (Fig. 3d). The slightly less-depleted value for January mimics exactly the shape of the rainfall isotope curve of Fig. 3b. This may imply a time of response of the river to rainfall over the winter half-year of $<1$ month, but displacement of floodplain storage (discussed further below) complicates this interpretation and it is probably safer to say that no clear response time can be deduced from comparison of the seasonal curves. This is not surprising for a mixed-BFI lowland river basin whose transit time (the mean travel time of water from entry to discharge) would be expected to be of the order of a decade by comparison with data from tritium-based studies compiled in McGuire and McDonnell (2006) and Stewart et al. (2010). Regrettably there is no tritium record for the Thames to test this.

Study of the data in Tables S1 and S2 suggests that river flow tends to vary inversely with $\delta^{18} \mathrm{O}_{\mathrm{r}}\left(\mathrm{r}^{2}=0.70\right)$. Flow was at its lowest in the autumn of 2003 , and the Thames at Wallingford most isotopically enriched. Although similar low flows occurred in 2005, 2010 and especially 2011, $\delta^{18} \mathrm{O}_{\mathrm{r}}$ never again became so enriched. A comparison of the Day's Weir and Thame flow data (obtained courtesy of the EA) shows that the Thame reached a particularly high percentage $(>20 \%)$ of the combined flow in the autumn of 2003; its relatively low BFI implies a greater potential for summer-early autumn evaporative 
enrichment. Perhaps the most notable flow events in the period 2003-2012 were the single flood peak of July 2007 (summer flooding on the Thames is rare) and the multiple flow peaks of winter 2012-13 following unusually high amounts of rainfall from April 2012 onwards (September excepted). In the case of the July 2007 flood, there was no obvious response of the river isotope composition, presumably because the monthly weighted mean rainfall of $-6.0 \%$ was similar to the summer river isotope composition. For the multiple floods of winter 2012-13, rainfall only became more isotopically depleted than the river 'envelope' in December 2012, with a value of $-8.5 \%$. This, combined with a January 2013 rainfall mean of $-9.0 \%$ was presumably responsible for a river composition of $-7.9 \%$ at the end of January 2013. While this was depleted relative to most monthly river values, it was just exceeded by the value of $-8.0 \%$ recorded in February 2010. Therefore it seems that flooding events are not necessarily or generally associated with highly anomalous isotope compositions. However, this would have to be tested by event-scale monitoring.

Delta-plots for the 15 tributaries sampled (see Fig. 1 and Tables 1 and S3) are shown in Fig. 4, all to the same scale. Also included on each plot is the Wallingford meteoric line as described above in eqn (1). Most data points fall on or near to this line, any significant deviations from it occurring with more isotopically enriched samples (e.g. the Cole, Cherwell and Ray), suggesting that evaporative fractionation is responsible. The proportion of river water lost to evaporation would not have to be large to cause the levels of isotopic enrichment observed. For example, in the case of the greatest enrichment found, in the Cole, Cherwell and Ray in October 2011 (Fig. 5, Table S3), and using the approach of Skrzypek et al. (2015), a fractional loss of $9 \%$ (based on $\delta^{18} \mathrm{O}$ ) or $12 \%$ (based on $\delta^{2} \mathrm{H}$ ) can be calculated. However, this assumes that the water starts evaporating with a composition equivalent to weighted mean rainfall and is not replenished thereafter, so these figures are indicative only.

Otherwise, the rivers show differing amounts of variation (Fig. 4). The Wye has the tightest distribution, varying little beyond measurement error, while the Ray has the greatest range at $2.1 \%$ in $\delta^{18} \mathrm{O}$ and $14 \%$ in $\delta^{2} \mathrm{H}$. When values of $\delta^{18} \mathrm{O}$ from each tributary and Wallingford rainfall (Tables S1 and S4) are compared over the quarterly sampling period it is clear that there is damping of $\delta^{18} \mathrm{O}_{\mathrm{r}}$ in relation to $\delta^{18} \mathrm{O}_{\mathrm{p}}$. However, this varies considerably, with the Wye showing the most damping and the Ray the least. In cases where the degree of damping is lower, it is possible to see tendencies towards winter depletion and summer enrichment (Fig. 5). Some of the latter may be due to evaporation, as mentioned above, but probably 
also to summer rainfall which is typically enriched (Fig. 3b). The lower-BFI rivers reach their most depleted compositions by April 2013, which follows the most sustained period of months (7) with rainfall more negative than the Thames mean of $-6.5 \%$. Conversely, plots of $\delta^{18} \mathrm{O}_{\mathrm{r}}$ versus flowrate (Fig. 5) shows the immunity of high-BFI rivers even to particularly wet periods such as summer 2011 to winter 2012/13.

Specific electrical conductivity SEC data for Thames-Wallingford 2003-2012 are included in Table S2. SEC varies by a factor of two, from a low of $470 \mu \mathrm{S} / \mathrm{cm}$ to a high of $980 \mu \mathrm{S} / \mathrm{cm}$, with a mean of $718 \mu \mathrm{S} / \mathrm{cm}$. When plotted against flow, SEC shows variable behaviour (Fig. 6a). While there is a general decrease with rise in flow rate up to $\sim 100 \mathrm{~m}^{3} / \mathrm{s}$, above this there is a return to higher values. There appears to be a 'January trend' where SEC barely changes with flow (Fig. 6a). $\mathrm{O}$ and $\mathrm{H}$ isotopes, here represented by $\delta^{18} \mathrm{O}_{\mathrm{r}}$ show very similar trends (Fig. 6b). As shown in Fig. 3d, January is normally the month of peak flow in the river, and indeed six of the eight months with mean flows $>100 \mathrm{~m}^{3} / \mathrm{s}$ (ultra-high flows, UHF) occur in January, the other two being the consecutive months November and December 2012, a notably wet period.

As suggested by a comparison between Figs $6 a$ and $b$, there is a positive correlation $\left(r^{2}=0.25\right)$ between SEC and $\delta^{18} \mathrm{O}_{\mathrm{r}}$ reflecting the tendency of lower-flow waters to be enriched in dissolved solids as well as isotopes owing to a combination of evaporation and proportionally greater inputs from non-rain-related sources such as baseflow and point-source inputs from sewage treatment works. Therefore the two parameters are to some extent proxies for each other. The main departure from this appears to be under UHF conditions where large amounts of isotopically-depleted rainfall have recently fallen, most notably November-December 2012 (Figs 6a and b, Tables S1 and S2).

The relative consistency of $\delta^{18} \mathrm{O}_{\mathrm{r}}$ and especially SEC values at UHF suggests that neither are attributable to direct runoff from high rainfall; if anything this would be expected to lower SEC, while consideration of the rainfall isotope record (Table S1) for each UHF month and the two preceding it give $\delta^{18} \mathrm{O}_{\mathrm{p}}$ weighted means ranging from -4.8 to $-9.6 \%$, i.e. far more variable than the observed $\delta^{18} \mathrm{O}_{\mathrm{r}}$ values. Clearly UHF conditions are mobilising stored water, which is presumably being displaced by rising groundwater levels. SEC and $\delta^{18} \mathrm{O}$ compositions close to river averages $(718 \mu \mathrm{S} / \mathrm{cm}$ and $-6.5 \%)$ suggest the involvement of bank storage rather than groundwater itself, which tends to have lower conductivity and a 
more depleted isotope composition (see further below). Given that alluvial deposits in the catchment above Wallingford cover some $500 \mathrm{~km}^{2}$, conservative estimates of thickness $(2 \mathrm{~m})$ and porosity (10\%) would give a storage volume of $100 \mathrm{Mm}^{3}$, easily sufficient to contribute a significant amount to the river under appropriate conditions. Most of the displaced water is likely to be coming from gravels, which have a porosity of up to $50 \%$.

The above interpretation would appear to be the reverse of what is generally understood by the term 'bank storage', whereby river water invades alluvial sediments at high flow and drains back to the river at lower flow (e.g. Chen and Chen, 2003). In reality, a normal bank storage regime may be the case for much of the Thames through most of the year, with the anomaly only occurring during situations when groundwater levels are still rising but the river falling. For example, Macdonald et al. (2012) noted that floodplain piezometer levels exceeded the river level near Oxford several times during the winter of 2009-10. A fuller examination of piezometric records from the catchment could conceivably shed more light on the processes involved, but was beyond the scope of the present paper.

A number of Thames sites at approximately $45 \mathrm{~km}$ intervals downstream from Cricklade $(\sim 10 \mathrm{~km}$ from the river head, see Fig. 1) were included in the quarterly monitoring of the tributaries. The results (Table S4) are compared in Fig. 7. Values of $\delta^{18} \mathrm{O}$ (Fig. 7a) are at their most unstable and enriched at the beginning of the period (October 2011) when river levels were low. In particular, the value at Wallingford appears to have been affected by evaporated inflows from the more significant clay-vale rivers (Cherwell and Thame). Conversely, during the very high flow of spring 2013 the Thames values are more depleted and very uniform. SEC values are similar in some respects to the $\delta^{18} \mathrm{O}$ values, with samples from October 2011 giving higher conductivities, and also reacting in all quarters to inputs from the Cherwell and Thame, but unlike the $\delta^{18} \mathrm{O}$ record the very high flow of spring 2013 does not stand out (Fig.7b).

The general uniformity down the river on any particular sampling date suggests that processes such as evaporation that would otherwise progressively affect the isotopes and other parameters are being mitigated by the addition of water from downstream tributaries and baseflow. 
Four sites (Wallingford, Tilehurst and Runnymede on the Thames, and Dorchester on the Thame, see Fig.1) were monitored at monthly intervals during the period between autumn 2011 and spring 2013 (Table S4) to determine what extra information might be obtainable from higher-resolution sampling.

Results for $\delta^{18} \mathrm{O}$ are shown in Fig. 8a. The higher sampling resolution found some sizeable peaks and troughs (mainly the latter), particularly during the high-flow periods in spring 2012 and winter 2012-13. There was little difference between any of the sites, presumably reflecting the origin of rainfall during large frontal events over southern England as a whole.

The close similarity between the changes in the Thame and Thames was somewhat unexpected given their contrasting catchment areas (Thame about one-fifth that of Thames). They differ more in SEC values (Fig. 8b), but both records still show comparable patterns of peaks and troughs.

\section{Baseflow and river-groundwater interaction}

Baseflow The spread in isotope values for each river should ideally have an inverse relationship with BFI because the greater the proportion of baseflow, generally expected to have a near-constant isotopic composition, the higher the potential for damping the variable composition of recent rainfall inputs. Figure $9 \mathrm{a}$ shows that this is largely the case, with a high degree of correlation for all tributaries (irrespective of mean flowrate) except for the Cherwell, Cole and Ray. The isotopic evidence above (Fig. 4) shows that the BFI-related range in these three rivers has been supplemented by evaporative enrichment, thereby distorting the relationship slightly. Greater-than-normal evaporation effects might be anticipated for a river like the Ray, which flows slowly through wetlands. Although less expected for the Cherwell, which has almost twice the flow of the Ray, in this case it is probably mostly attributable to the existence of the Oxford Canal which shares water with the Cherwell at several locations above the sampling point (Neal et al., 2006), providing more scope for evaporative enrichment to affect the river. The Cherwell, Ray and Cole are also proportionally more effluent-impacted than most of the other tributaries (Bowes et al., 2014), though the limited effluent isotope data so far available from the Upper Thames suggest that discharge waters are not significantly fractionated (D C Gooddy pers. commun.). 
Variations in SEC (Table S3) to some extent follow those shown by the $\mathrm{O}$ and $\mathrm{H}$ stable isotopes (Fig. 5) insofar as the Cherwell and Ray have the largest spreads. However the Cole shows only a modest range of SEC, while The Cut has one of the largest, both contrary to their isotope record. This shows that SEC is not always a proxy for stable isotopes. The reason for this is that the different tributaries have differing hydrochemical properties depending on several factors, geology probably being the most important. Since BFI is a primary function of catchment geology (Bloomfield et al., 2009) a correlation might be expected with SEC. As Fig. 9b shows, this is basically the case though there are some exceptions. The high-BFI rivers are those in Oolite or Chalk catchments, where SEC is basically controlled by calcite solubility. Thus there is little change in SEC for BFIs above 0.80. Below this, however, the river water quality data ( $\mathrm{CEH}$, unpublished data) show that sulphate is the dominant ion responsible for the increase in total dissolved solids and therefore SEC. In the clay-vale rivers this could be derived from $\mathrm{SO}_{4}$ from dissolution or oxidation of the S-containing minerals typically found in clays, but more likely from fertiliser runoff. The Enborne is the only exception to the trends in Fig. 9b; although a low-BFI river it also has unusually low SEC values. The reason for this is probably catchment shape (e.g. Rinaldo et al., 1995): Fig. 1 shows that this tributary has a very narrow catchment, which means short, low-residence flow paths to the river. This in turn means that there is insufficient time for the water to reach chemical equilibrium with the soil or rocks through which it is passing. None of the other rivers considered here has a similarly-constricted catchment.

Except for the very low-flow quarterly sampling of October 2011, the simple average of SEC in the tributaries was almost identical to the simple average of SEC from the five Thames sampling points (from data in Table S3).

Relationship of surface water to groundwater This can be considered on the local and catchment scales. As an example of the former, downstream of Wallingford the Thames crosses the Chalk escarpment via the Goring Gap (Fig. 1), where modelling studies suggest that the potential for recharge of the river by groundwater exists (Jackson et al., 2006). The river accretes an average flow of $\sim 5.5 \mathrm{~m}^{3} / \mathrm{s}$ between Wallingford and Reading (Day's Lock + Wheatley compared to Reading, Table 1). The only significant tributary is the Pang, which provides $\sim 12 \%$ of the increased flow (Table 1). Therefore it is likely that groundwater is contributing, since direct runoff does not occur from the Chalk. While there is some contrast 
between river and groundwater isotope values, this was not great enough to show up at Tilehurst (west Reading) in Fig. 8a given that the accretion is only increasing flow by $\sim 17 \%$. However, SEC was consistently 5\% lower at Tilehurst (Fig. 8b), which would be in accord with the significantly lower SEC of groundwater compared to river water (see below).

On the catchment scale, BFI values (Table 1) indicate that even rivers with large areas of low-permeability cover in their catchments like the Ray and The Cut have a baseflow component approaching 50\% of mean flow, while the Coln and the Pang consist of little else. This raises the question of the extent to which groundwater isotopic signals are preserved in the various rivers of the catchment. The following groundwater quality studies carried out in the upper Thames region allow a comparison: Alexander and Andrews (1984), Bearcock and Smedley (2010), Cobbing et al. (2004), Darling et al. (2012), Edmunds et al. (1987), Jackson et al. (2006) and Neumann et al. (2003).

A co-plot of groundwater $\delta^{18} \mathrm{O}$ and $\delta^{2} \mathrm{H}$ values (inset to Fig. 10) shows that they are wellcorrelated and tend to follow the Wallingford meteoric water line. Most results cluster in the range -7.0 to $-7.5 \%$ o $\delta^{18} \mathrm{O}$, which is distributed around the 2003-2012 Wallingford rainfall weighted mean of $-7.22 \%$, and conforms with the view of Darling et al. (2003) that no significant seasonal isotopic selection occurs during the groundwater recharge process in the region. Figure 10a shows the distribution of groundwater $\delta^{18} \mathrm{O}$ across the catchment. There is evidence for a slight isotopic enrichment from north to south, consistent with the latitudinal distribution of rainfall isotopes in southern England as proposed by Darling et al. (2003).

A simple comparison with river baseflow compositions is however not straightforward. For the quarterly sampling of October 2011, which followed a prolonged dry spell, the rivers would have been sustained largely by baseflow. However, all rivers with the exception of the Wye contained water more enriched than $-7 \% \delta^{18} \mathrm{O}$, some much more so. This is likely to have been due to isotopic enrichment caused by evaporative fractionation, as mentioned earlier. Study of Fig. 5 suggests that the quarterly sampling most representative of baseflow conditions was probably April 2012, following a dry winter but prior to the anomalously wet summer and even wetter winter of 2012-13. On this basis, a comparison of Fig. 10a with Fig. 4 shows that only a few short limestone or chalk streams (Coln, Pang and Wye) have a composition largely unaffected by evaporation. The Kennet, while slightly enriched by comparison, is probably also mostly unaffected since it is likely to be mainly sustained by 
slightly isotopically heavier groundwater in the south of the region (Fig. 10a). Most of the largest enrichments were seen in the clay-vale rivers Loddon, Thame, Ray and The Cut. Clearly, except for short, high-BFI rivers, it is unsafe to regard samples taken at any particular time of the year as having the same isotope value as the groundwater contributing the baseflow.

The net effect on the main Thames is that the river is nearly always isotopically enriched compared to groundwater in the region even in the winter, though this is minor compared to late summer-early autumn. As noted earlier in connection with Fig. 7, there is rather little change down the river for individual quarterly samplings, suggesting that increasing downstream enrichment due to progressive evaporation is cancelled out by inflow derived from tributaries and baseflow.

In terms of SEC, under the presumed near-baseflow conditions of the April 2012 sampling, the tributaries averaged $669 \mu \mathrm{S} / \mathrm{cm}$ and the Thames $692 \mu \mathrm{S} / \mathrm{cm}$ (from data in Table S3). This is $\sim 15 \%$ higher than the average groundwater value of $\sim 600 \mu \mathrm{S} / \mathrm{cm}$ (data from sources cited above) and would be consistent with the effects of evaporation on baseflow, though effluent inputs with higher SEC (of the order of $1000 \mu \mathrm{S} / \mathrm{cm}$ ) will also contribute (on average $10 \%$ of MDF at Wallingford).

However, a caveat to consider with regard to both $\delta^{18} \mathrm{O}$ and SEC is that aquifer groundwater as sampled from boreholes is not necessarily the only contributor to baseflow. This is really an inclusive term for all forms of 'slow' drainage to a river (e.g. Ward and Robinson, 2000), which may include delayed drainage from the shallow subsurface which by-passes the underlying aquifer. It is conceivable, particularly for the clay-vale rivers, that this slowermoving but shallow drainage might have undergone a certain amount of isotopic modification before reaching the river (a possibility raised in connection with US rivers by Kendall and Coplen, 2001). However, testing this (presumably by shallow drilling and sampling) was beyond the resources of the present study.

Figures $8 \mathrm{a}$ and $8 \mathrm{~b}$ show no evidence of consistent differences in $\delta^{18} \mathrm{O}$ or SEC between 'Jurassic' Thames as sampled at Wallingford, and 'Cretaceous + Palaeogene' Thames as sampled at Runnymede. While the record of the latter would of course be superimposed on 
the former, they do contribute approximately equal flow volumes according to the long-term gauge records (Day's Lock + Wheatley compared to Bray, Table 1).

\section{Dissolved inorganic carbon}

The source of most dissolved inorganic carbon (DIC) in the natural waters of lowland Britain is the dissolution by soil-produced $\mathrm{CO}_{2}$ of carbonate minerals in the soil and bedrock of the catchment. Soil $\mathrm{CO}_{2}$ with $\delta^{13} \mathrm{C}$ of $\sim-27 \%$ (Darling and Gooddy, 2007) reacts with carbonate minerals with $\delta^{13} \mathrm{C}$ typically $\sim 0 \%$ (Evans et al., 1979) to produce initial $\delta^{13} \mathrm{C}$-DIC values in the range -13 to $-14 \%$. Once waters are exposed to the atmosphere, the DIC budget is governed by three basic processes: degassing, oxidation of organic matter, and photosynthesis (e.g. Jarvie et al., 1997). These processes have varying isotopic effects.

Exposure to air generally results in degassing (evasion) of $\mathrm{CO}_{2}$ owing to its low atmospheric partial pressure compared to the $p \mathrm{CO}_{2}$ of most river waters (e.g. Hotchkiss et al., 2015). Loss of $\mathrm{CO}_{2}$ raises $\mathrm{pH}$, which tends to reduce DIC concentration while enriching $\delta^{13} \mathrm{C}$-DIC. Oxidation of organic matter, by microbial respiration in the soil and river channel, may contribute surplus $\mathrm{CO}_{2}$ (i.e. in excess of that taken up by mineral dissolution) with a value of $\sim-27 \%$. This tends to make $\delta^{13} \mathrm{C}$-DIC values more negative than the theoretical simple dissolution value, while raising DIC concentration. Photosynthesis has a similar effect to outgassing, so cannot easily be resolved from outgassing on the basis of $\delta^{13} \mathrm{C}$-DIC and alkalinity alone. Isotopic exchange with the atmosphere would raise $\delta^{13} \mathrm{C}$-DIC values towards $\sim 0 \%$ (e.g. Kanduč et al, 2007) but this can be ruled out for the rivers of the upper Thames basin which all have relatively high alkalinities.

Results for the Thames at Wallingford during the period 2003-2007 are reported in Table S5, together with $\mathrm{pH}$ and alkalinity. There is little variation in $\delta^{13} \mathrm{C}$ when the data are considered on an inter-annual basis, with average values lying within $\pm 0.5 \%$ about a mean of $-14.8 \%$. Inter-quartile ranges also remain similar. There is similar consistency in $\mathrm{pH}$ and alkalinity. Seasonal statistics on the other hand reveal some seasonal fluctuations in $\delta^{13} \mathrm{C}$-DIC, alkalinity and $p \mathrm{CO}_{2}$ (Fig. 11a-c). The carbon isotope composition of the river at any one time is the result of interaction between the three processes outlined above superimposed on any groundwater or effluent contribution. Values of $\delta^{13} \mathrm{C}$-DIC are poorly correlated with alkalinity, indicating that no single process predominates, and consistent with the observation 
that most aquatic systems show a fluctuating respiration-photosynthesis balance (e.g. Wang and Veizer, 2000). However, given that $\log p \mathrm{CO}_{2}$ values in the range -2.2 to -2.8 are an order of magnitude above atmospheric $\mathrm{CO}_{2}(\sim-3.4$ for the period), it appears that evasion must be a relatively constant factor, though with a somewhat greater potential in the period May-September. Perhaps surprising is that the relatively large inter-quartile ranges in alkalinity (and to a lesser extent $p \mathrm{CO}_{2}$ ) from August to December are not reflected by $\delta^{13} \mathrm{C}$ DIC.

At this point it must be noted that the main River Thames and at least some of its tributaries are in a far from natural state; there is for example considerable recycling of river water in the Oxford, Reading and other urbanised areas through abstraction for public supply and subsequent return of effluent, not necessarily within the same sub-catchment. For this reason alone it would be difficult to predict what effect effluent might have on dissolved inorganic carbon isotopes at any particular location. However it is also the case that the effects on $\delta^{13} \mathrm{C}$-DIC of urban effluents can be variable: mineralisation of organic carbon would tend to lower $\delta^{13} \mathrm{C}$-DIC (Barth et al, 2003), but compounds such as detergents could raise it (Shin et al., 2015). On the other hand, Wachniew (2006) found no change in $\delta^{13} \mathrm{C}$-DIC in the River Vistula flowing through Warsaw (pop. $1.7 \mathrm{M}$ ) despite half that city's sewage effluent remaining untreated. Furthermore, on a much smaller scale, Morrissey et al. (2012) found little or no evidence of change in macroinvertebrate $\delta^{13} \mathrm{C}$ below effluent outfalls in UK urban streams. It seems probable therefore that the Thames at Wallingford has not been significantly impacted (at least in isotopic terms) by effluent-derived DIC.

Plots of tributary $\delta^{13} \mathrm{C}$-DIC and alkalinity (Table S6) against time are shown in Fig. 12. In most cases minimum $\delta^{13} \mathrm{C}$-DIC values are seen for the two October samplings, presumably due to a temporary dominance in respiration (supported by a general rise in $p \mathrm{CO}_{2}$ compared to April 2012), and possibly the effects of a proportionately higher contribution of sewage effluent, though the Morrissey et al. (2012) study suggests not. Highest $\delta^{13} \mathrm{C}$-DIC values are generally seen for the April 2012 sampling, consistent with photosynthesis, which peaks in the spring (Neal et al., 1998), but are not replicated in the April 2013 sampling, when $\delta^{13} \mathrm{C}$ falls. River flows had by then recently been so high (Fig. 5) that the usual seasonal processes may have been to some extent overridden by an abnormally high influx of soil water (see e.g. Griffiths et al., 2007), charged with isotopically-depleted soil-zone $\mathrm{CO}_{2}$. The concurrent universal fall in alkalinity would be indicative of such a dilution effect. 
For the main Thames, most $\delta^{13} \mathrm{C}$-DIC series tend to vary rather little between the sampling sites though there is a certain amount of seasonal displacement with little apparent pattern (Fig. 7c). The October 2012 series however shows one large variation and significant displacement from the other quarters, though the cause remains unknown. Alkalinity also shows seasonal displacement, but with more longitudinal consistency, falling universally between Sonning and Runnymede (Fig 7d). After an initial fall between Hannington and Swinford, which would be typical of a baseflow-influenced upper watercourse (e.g. Kanduč et al., 2007), $p \mathrm{CO}_{2}$ values generally rise slightly along the river irrespective of the season/flow conditions so probably not related to the slight increase in BFI between Day's Lock and Bray (Table 1). Given the variety of processes controlling dissolved $\mathrm{CO}_{2}$ (Neal et al., 1998) this consistency is perhaps surprising, but it does suggest that the potential for evasion exists along the river throughout the year (Fig. 7e).

As with $\delta^{18} \mathrm{O}$, the magnitude of changes in $\delta^{13} \mathrm{C}$-DIC and alkalinity might be expected to be linked to BFIs. A comparison of Tables 1 and S5 shows that to some extent this is the case, with low-BFI rivers like the Cole (0.53) and the Ray (0.49) showing significantly larger changes in $\delta^{13} \mathrm{C}$-DIC and alkalinity than high-BFI rivers like the Coln (0.95) and the Windrush (0.87). However, there are exceptions like the chalk streams Kennet, Pang and Wye $(0.87$ to 0.94$)$ which have relatively large fluctuations in $\delta^{13} \mathrm{C}$-DIC, and intermediateBFI rivers like the Evenlode (0.71) and the Loddon (0.69) which show less change. It is therefore likely that in addition to fluctuations in the respiration-photosynthesis-evasion balance, variations in $\delta^{13} \mathrm{C}$-DIC between the rivers are due to a complex interaction between river length, catchment geology and anthropogenic factors, and consequently difficult to unravel.

Figure $10 \mathrm{~b}$ shows the distribution of groundwater $\delta^{13} \mathrm{C}$-DIC values. Samples from the Jurassic and Cretaceous parts of the basin fall in the range -12 to $-16 \%$, while those from the Palaeogene lie in the range -17.5 to $-19 \%$ o (though there are many fewer samples from the Palaeogene because it generally makes a poor aquifer). As outlined earlier, $\delta^{13} \mathrm{C}$-DIC values in groundwater are the consequence of soil $\mathrm{CO}_{2}$ reacting with rock carbonate combined with further modification by various processes. An initial $\delta^{13} \mathrm{C}$-DIC value of $\sim-13 \%$ can be made more positive by further dissolution-precipitation reactions, and more negative by further equilibration with soil-derived $\mathrm{CO}_{2}$ (i.e. closed- and open-system conditions respectively). 
The $\delta^{13} \mathrm{C}$-DIC values in Fig. 10b show that most if not all of the groundwaters are evolving under open-system conditions, though there is a difference in the extent of this between the Oolite or Chalk waters compared with the Palaeogene. Limestone and chalk groundwater alkalinities as $\mathrm{HCO}_{3}$ are invariably $>220 \mathrm{mg} / \mathrm{L}$ but the Palaeogene waters, from what are basically sandstone aquifer units, are all $<150 \mathrm{mg} / \mathrm{L}$ (data from sources used for Fig. 10). They are therefore much less buffered against re-equilibration with soil-derived $\mathrm{CO}_{2}$, and consequently more depleted in ${ }^{13} \mathrm{C}$.

The Cut, Enborne and Loddon all have low alkalinities compared to the other tributaries (Table S6), reflecting their origins on the Palaeogene strata. This difference however does not extend to their $\delta^{13} \mathrm{C}$-DIC values, which cannot be distinguished from the other rivers. The three basic processes acting on surface waters outlined earlier (respiration, photosynthesis and evasion) are clearly very effective in overprinting the $\delta^{13} \mathrm{C}$ values of baseflow contributions.

\section{CONCLUSIONS}

The aim of this study has been to investigate the processes operating in a mesoscale lowland river basin using environmental tracers (stable isotopes and specific electrical conductivity) on temporal and areal scales rarely attempted previously. It has been achieved over a period which included both drought and flood conditions. The results should therefore be highly representative of the behaviour of similar temperate-zone catchments under the likely range of present climatic conditions.

Insights obtained included the following:

Based on $\delta^{18} \mathrm{O}$ and $\delta^{2} \mathrm{H}$ data, the upper Thames and most of its tributaries showed evidence of evaporative enrichment compared to rainfall in the area. The extent of this varied seasonally. Calculations suggested that relatively low amounts of evaporation would achieve the observed enrichments.

While the Thames varied within a range of $3 \%$ in $\delta^{18} \mathrm{O}$ and $20 \%$ in $\delta^{2} \mathrm{H}$, little information about the response time of the various water compartments in the basin could be extracted 
from the isotope data. However, $\delta^{18} \mathrm{O}$ and specific electrical conductivity (SEC) showed strong evidence for a release of bank-stored water under highest river flow conditions, in apparent contravention of the normal bank storage process.

For most tributaries, baseflow index was revealed to be highly correlated with the magnitude of $\delta^{18} \mathrm{O}$ change from drought to flood conditions. Despite this, comparison with previouslyobtained hydrogeochemical data suggests that rivers even at low flow rarely consist wholly of unfractionated groundwater.

In terms of tracing groundwater inputs to rivers, SEC is likely to be a more sensitive indicator than $\mathrm{O}$ or $\mathrm{H}$ stable isotopes because of the greater contrast between river and groundwater. However, on a local scale when river water may be invading superficial sediments owing to pumping or other effects, isotopes may provide confirmation (e.g. Jackson et al., 2006).

The results of $\delta^{13} \mathrm{C}$-DIC, $\mathrm{pH}$ and alkalinity measurements showed that while the river system as a whole probably always has evasion potential, thus counteracting any tendency towards isotopic equilibration with atmospheric $\mathrm{CO}_{2}$, there is a complex interaction between respiration, photosynthesis and degassing and catchment factors which is difficult to unravel. Indeed, these processes proved to be very effective at masking the origin of individual rivers' baseflow components.

These insights will contribute to a better understanding of the functioning of a lowland river basin in a water-critical area, and demonstrate the value of long-term river monitoring using environmental tracers. 


\section{ACKNOWLEDGMENTS}

The original scope of this study was greatly enhanced by the cooperation of the NERCfunded Thames Initiative research platform of the Centre for Ecology and Hydrology (CEH) in the collection of river water samples and provision of supporting data. The authors are grateful to the following: Colin Roberts and Pete Scarlett $(\mathrm{CEH})$ for the quarterly sample collection; Heather Wickham (CEH) for sample organisation; Milly Lewis (BGS) for sample collection at Tilehurst; Gillian Wells (Environment Agency) for river flow data; Steph Bricker (BGS) for the geology map used in Figs 1 and 10; Andy Newell (BGS) for further geological advice; and Thames Water Utilities Ltd for information on the use of their Farmoor reservoir. Terry Marsh (CEH) is thanked for commenting on an earlier draft of the manuscript. Also thanked are two anonymous referees, whose comments helped to improve the structure and content of this paper. WGD contributes with the permission of the Executive Director, British Geological Survey (NERC). 


\section{REFERENCES}

Alexander J, Andrews J N (1984) Hydrogeological investigations in the Harwell region: the use of environmental isotopes, inert gas contents and the uranium decay series. British Geological Survey Report FLPU 84-7, Keyworth, UK.

Andrews F M (1962) Some aspects of the hydrology of the Thames Basin. Proceedings of the Institute of Civil Engineers 21, 55-90.

Amiotte-Suchet P, Aubert D, Probst J L, Gauthier-Lafaye F, Probst A, Andreux F, Viville D (1999) $\delta^{13} \mathrm{C}$ pattern of dissolved inorganic carbon in a small granitic catchment: the Strengbach case study (Vosges Mountains, France). Chemical Geology 159, 129-145.

Aucour A-M, Sheppard S M F, Guyomar O, Wattelet J (1999) Use of ${ }^{13} \mathrm{C}$ to trace origin and cycling of inorganic carbon in the Rhone River system. Chemical Geology 159, 87-105.

Barth J A C, Cronin A A, Dunlop J, Kalin R M (2003) Influence of carbonates on the riverine carbon cycle in an anthropogenically dominated catchment basin: evidence from major elements and stable carbon isotopes in the Lagan River (N. Ireland). Chemical Geology 200, 203-216.

Bearcock J M, Smedley P L (2010) Baseline groundwater chemistry: the Palaeogene of the Thames Basin. British Geological Survey Open Report, OR/10/057, 77pp.

Bloomfield J P, Allen D J, Griffiths K J (2009) Examining geological controls on baseflow index (BFI) using regression analysis: An illustration from the Thames Basin, UK. Journal of Hydrology 373, 164-176.

Bloomfield J P, Bricker A J, Newell A J (2011) Some relationships between lithology, basin form and hydrology: a case study from the Thames basin, UK. Hydrological Processes 25, 25182530 .

Bowes M J, Jarvie H P, Naden P S, Old G H, Scarlett P M, Roberts C, Armstrong L K, Harman S A, Wickham H D, Collins A L (2014) Identifying priorities for nutrient mitigation using river concentration-flow relationships: the Thames basin, UK. Journal of Hydrology 517, 1-12.

Burns DA, McDonnell JJ. 1998. Effects of a beaver pond on runoff processes: comparison of two headwater catchments. Journal of Hydrology 205, 248-264.

Cameron E M, Hall G E M, Veizer J, Krouse H R (1995) Isotopic and elemental hydrogeochemistry of a major river system; Fraser River, British Columbia, Canada. Chemical Geology 122, 149-169.

Candy I, Schreve D (2007) Land-sea correlation of Middle Pleistocene temperate sub-stages using high-precision uranium-series dating of tufa deposits from southern England. Quaternary Science Reviews 26, 1223-1235. doi: 10.1016/j.quascirev.2007.01.012.

Chen X, Chen X (2003) Stream water infiltration, bank storage, and storage zone changes due to stream-stage fluctuations. Journal of Hydrology 280, 246-264. 
Clark I D, Fritz P (1997) Environmental Isotopes in Hydrogeology. CRC Press, 352pp.

Cobbing J E Moreau M, Shand P, Lancaster A, Hargreaves R L (2004) Baseline report series. 14, The Corallian of Oxfordshire and Wiltshire: British Geological Survey report CR/04/262N, 48pp.

Craig H (1961) Isotopic variations in meteoric waters. Science 133, 1702-1703.

Dansgaard W (1964) Stable isotopes in precipitation. Tellus 16, 436-468.

Darling W G, Talbot J C (2003) The O \& H stable isotopic composition of fresh waters in the British Isles. 1. Rainfall. Hydrology \& Earth System Sciences 7, 163-181.

Darling W G, Gooddy D C (2007) Assessing the applicability of global CFC and SF 6 input functions to groundwater dating in the UK. Science of the Total Environment 387, 353-362.

Darling W G, Bath A H, Talbot J C (2003) The O \& H stable isotopic composition of fresh waters in the British Isles. 2. Surface waters and groundwater. Hydrology \& Earth System Sciences 7, 183-195.

Darling W G, Gooddy D C, Morris B L, Peach D W (2012) The hydrochemistry of a Chalk aquifer during recovery from drought. Quarterly Journal of Engineering Geology and Hydrogeology 45, 473-486.

Edmunds W M, Cook J M, Darling W G, Kinniburgh D G, Miles D L, Bath A H, Morgan-Jones M, Andrews J N (1987). Baseline geochemical conditions in the Chalk aquifer, Berkshire, UK: a basis for groundwater quality management. Applied Geochemistry 2, 251-274.

Evans G V, Otlet R L, Downing R A, Monkhouse R A, Rae G (1979) Some problems in the interpretation of isotope measurements in United Kingdom aquifers. In: Isotope Hydrology 1978, Vol II, IAEA, Vienna, 679-706.

van Geldern R, Schulte P, Mader M, Baier A, Barth JA (2015) Spatial and temporal variations of $p \mathrm{CO}_{2}$, dissolved inorganic carbon and stable isotopes along a temperate karstic watercourse.

Hydrological Processes 29, 3423-3440.

Griffiths J, Nutter J, Binley A, Crook N, Young A, Pates J (2007) Variability of dissolved $\mathrm{CO}_{2}$ in the Pang and Lambourn Chalk rivers. Hydrology \& Earth System Sciences 11, 328-339.

Halder J, Terzer S, Wassenaar L I, Araguás-Araguás L J, Aggarwal P K (2015) The Global Network of Isotopes in Rivers (GNIR): integration of water isotopes in watershed observation and riverine research, Hydrology and Earth System Sciences 19, 3419-3431, doi:10.5194/hess19-3419-2015.

Hogan J F, Blum J D (2003) Tracing hydrologic flow paths in a small forested watershed using variations in ${ }^{87} \mathrm{Sr} /{ }^{86} \mathrm{Sr}, \mathrm{Ca} / \mathrm{Sr}, \mathrm{Ba} / \mathrm{Sr}$ and $\delta^{18} \mathrm{O}$. Water Resources Research 39, doi:10.1029/2002WR001856. 
Hotchkiss E R, Hall R O, Sponseller R A, Butman D, Klaminder J, Laudon J, Rosvall M,

Karlsson J (2015) Sources of and processes controlling CO2 emissions change with the size of streams and rivers. Nature Geoscience 8, 696-699, doi:10.1038/ngeo2507.

Hughes S S, Millard A R, Lucy S J, Chenery C A, Evans J A, Nowell G, Pearson D G (2014) Anglo-Saxon origins investigated by isotopic analysis of burials from Berinsfield, Oxfordshire, UK. Journal of Archaeological Science 42, 81-92. 10.1016/j.jas.2013.10.025.

Jackson C R, Bloomfield J P, Buckley D K, Chambers J E, Darling W G, Hughes A G, Mansour M M, Newell A J, Peach D W, Raines, M G (2006) Conceptualisation of groundwater flow in the Chalk aquifer around Gatehampton. British Geological Survey report CR/06/206C, 132pp. Jarvie H P, Neal C, Leach D V, Ryland G P, House W A, Robson A J (1997) Major ion concentrations and the inorganic carbon chemistry of the Humber rivers. Science of the Total Environment 194/195, 285-302.

Jenkins G, Perry M, Prior J (2009) The climate of the United Kingdom and recent trends. Rep. Hadley Centre, Met Office, Exeter, 118 pp.

Jolley T J, Wheater H S (1996) A large-scale grid-based hydrological model of the Severn and Thames catchments. Water and Environment Journal 10, 253-262.

Kanduč T, Szramek K, Ogrinc N, Walter L M (2007) Origin and cycling of riverine inorganic carbon in the Sava River watershed (Slovenia) inferred from major solutes and stable carbon isotopes. Biogeochemistry 86, 137-154.

Keatings K W, Heaton T H E, Holmes J A (2002) Carbon and oxygen isotope fractionation in non-marine ostracods: results from a 'natural culture' environment. Geochimica et Cosmochimica Acta 66, 1701-1711.

Kendall C, Coplen T B (2001) Distribution of oxygen-18 and deuterium in river waters across the United States. Hydrological Processes 15, 1363-1393

Kendall C, McDonnell J J (eds) (1998) Isotope tracers in catchment hydrology. Elsevier, Amsterdam, 838 pp.

Macdonald D M J, Griffiths K J, Lapworth D J, Williams P J, Stuart M E, Gooddy D C (2012) Hydrogeochemical characterisation of a peri-urban floodplain: initial findings. Rep. British Geological Survey IR/12/049, Keyworth, UK, 85pp.

Marsh T J, Hannaford J (Eds) (2008) UK Hydrometric Register. Hydrological data UK series. Centre for Ecology \& Hydrology, 210pp.

McGuire K J, McDonnell J J (2006) A review and evaluation of catchment residence time modeling. Journal of Hydrology 330, 543-563.

McGuire K J, McDonnell J J (2015) Preface: tracers advances in catchment hydrology. Hydrological Processes 29, 5135-5138. 
Morrissey C A, Boldt A, Mapstone A, Newton J, Ormerod S J (2012) Stable isotopes as indicators of wastewater effects on the macroinvertebrates of urban rivers. Hydrobiologia, doi:10.1007/s10750-012-1233-7.

Neal C, Harrow M, Williams R J (1998) Dissolved carbon dioxide and oxygen in the River Thames: spring-summer 1997. Science of the Total Environment 210, 205-217.

Neal C, Neal M, Hill L, Wickham H (2006) River water quality of the River Cherwell: An agricultural clay-dominated catchment in the upper Thames Basin, southeastern England. Science of the Total Environment 360, 272-289.

Neumann I, Brown S, Smedley P L, Besien, T (2003) Baseline Report Series: 7. The Great and the Inferior Oolite of the Cotswold district. British Geological Survey report CR/03/202N, 62pp.

Ogrinc N, Kanduč T, Stichler W, Vreča P (2008) Spatial and seasonal variations in $\delta^{18} \mathrm{O}$ and $\delta \mathrm{D}$ values in the River Sava in Slovenia. Journal of Hydrology 359, 303-312.

Pawellek F, Frauenstein F, Veizer J (2002) Hydrochemistry and isotope geochemistry of the upper Danube River. Geochimica et Cosmochimica Acta 66, 3839-3854.

Ramesh R, Sarin M M (1992) Stable isotope study of the Ganga (Ganges) river system. Journal of Hydrology 139, 49-62.

Rinaldo A, Vogel G K, Rigon R, Rodríguez-Iturbe I (1995) Can one gauge the shape of a basin? Water Resources Research 31, 1119-1127.

Rozanski K, Araguas-Araguas L, Gonfiantini R (1993) Isotopic patterns in modern global precipitation. In Climate Change in Continental Isotopic Records, American Geophysical Union, Geophysical Monograph 78, 1-37.

Shin W J, Lee K S, Park Y, Lee D, Yu E J (2015) Tracing anthropogenic DIC in urban streams based on isotopic and geochemical tracers. Environmental Earth Sciences 74, 2707-2717.

Schulte P, van Geldern R, Freitag H, Karim A, Negrel P, Petelet-Giraud E, Probst A, Probst J L, Telmer K, Veizer J, Barth J A C (2011) Applications of stable water and carbon isotopes in watershed research: weathering, carbon cycling, and water balances. Earth-Science Reviews 109, $20-31$.

Sklash M G and Farvolden R N (1979) The role of groundwater in storm runoff. Journal of Hydrology 12, 45-65.

Skrzypek G, Mydłowski A, Dogramaci S, Hedley P, Gibson J J, Grierson P F (2015) Estimation of evaporative loss based on the stable isotope composition of water using Hydrocalculator. Journal of Hydrology 523, 781-789.

Speed M, Tetzlaff D, Soulsby C, Hrachowitz M, Waldron S (2010) Isotopic and geochemical tracers reveal similarities in transit times in contrasting mesoscale catchments. Hydrological Processes 24, 1211-1224. 
Stewart M K, McDonnell J J (1991) Modeling base flow soil water residence times from deuterium concentrations. Water Resources Research 27, 2681-93.

Stewart M K, Morgenstern U, McDonnell J J (2010) Truncation of stream residence time: How the use of stable isotopes has skewed our concept of streamwater age and origin. Hydrological Processes 24, 1646-1659.

Versteegh E A A, Black S, Canti M G, Hodson M E (2013) Earthworm-produced calcite granules: a new terrestrial palaeothermometer? Geochimica et Cosmochimica Acta 123, 351-357. doi:10.1016/j.gca.2013.06.020.

Wachniew P (2006) Isotopic composition of dissolved inorganic carbon in a large polluted river: The Vistula, Poland. Chemical Geology 233, 293-308.

Wang X and Veizer J (2000) Respiration-photosynthesis balance of terrestrial aquatic ecosystems, Ottawa area, Canada. Geochimica et Cosmochimica Acta 64, 3775-3786.

Ward RC, Robinson M (2000) Principles of Hydrology, $4^{\text {th }}$ edn, McGraw-Hill, London and New York, 450pp. 
Table 1. Sampling locations for the Thames and tributaries in the upper river basin. Also included are values for mean flow and baseflow index, and gauging station details. Cases where the gauging point is $>1 \mathrm{~km}$ from the sampling point are noted.

\begin{tabular}{|c|c|c|c|c|c|c|c|c|c|}
\hline \multirow[t]{2}{*}{ River } & \multirow[t]{2}{*}{ Sampling point } & \multicolumn{2}{|c|}{ NGR } & \multirow[t]{2}{*}{ Nearest gauge } & \multirow[t]{2}{*}{ EA no. } & \multirow{2}{*}{$\begin{array}{c}\text { Mean flow } \\
\mathrm{m}^{3} / \mathrm{s} \\
\end{array}$} & \multirow[t]{2}{*}{ BFI } & \multirow[t]{2}{*}{ Period } & \multirow[t]{2}{*}{ Notes } \\
\hline & & $\mathbf{E}$ & $\mathbf{N}$ & & & & & & \\
\hline Coln & Whelford & 417121 & 199200 & Fairford & 39110 & 1.99 & 0.95 & $1991-2005$ & $\sim 3 \mathrm{~km} \mathrm{D}$ of gauge \\
\hline Cole & Lynt Bridge & 421057 & 198107 & Inglesham & 39090 & 1.20 & 0.53 & 1976-2005 & \\
\hline Leach & Lechlade & 422700 & 199320 & Lechlade & 39042 & 0.75 & 0.79 & $1972-2005$ & \\
\hline Windrush & Newbridge & 440179 & 201858 & Newbridge & 39006 & 3.29 & 0.87 & 1996-2005 & \\
\hline Evenlode & Cassington Mill & 444853 & 209919 & Cassington Mill & 39034 & 3.72 & 0.71 & $1950-2005$ & \\
\hline Cherwell & Hampton Poyle & 449912 & 215282 & Enslow Mill & 39021 & 3.81 & 0.66 & $1969-2005$ & $\sim 4 \mathrm{~km} \mathrm{D}$ of gauge \\
\hline Ray & Is lip & 452320 & 213730 & Is lip & 39140 & 2.01 & 0.49 & $1962-2005$ & \\
\hline Ock & Abingdon & 448148 & 196667 & Abingdon & 39081 & 1.53 & 0.64 & 1972-2005 & \\
\hline Thame & Wheatley & 461190 & 205030 & Wheatley & 39105 & 3.79 & 0.59 & $1970-2005$ & \\
\hline Pang & Tidmarsh & 463600 & 174700 & Pangbourne & 39027 & 0.65 & 0.87 & $1968-2005$ & $\sim 1.5 \mathrm{~km} \mathrm{U}$ of gauge \\
\hline Kennet & Woolhampton & 457120 & 166462 & Theale & 39016 & 9.75 & 0.87 & $1995-2005$ & $\sim 7 \mathrm{~km} \mathrm{U}$ of gauge \\
\hline Enborne & Brimpton & 456783 & 164772 & Brimpton & 39025 & 1.33 & 0.54 & $1967-2005$ & \\
\hline Loddon & Charvil & 477872 & 176587 & Twyford & 39138 & 6.68 & 0.69 & 1965-2005 & \\
\hline Wye & Bourne End & 489612 & 186580 & Hedsor Mill & 39023 & 1.01 & 0.94 & 1964-2005 & \\
\hline The Cut & Paley Street & 487037 & 176290 & Binfield & 39052 & 0.39 & 0.46 & $1957-2005$ & $\sim 6 \mathrm{~km} \mathrm{D}$ of gauge \\
\hline Thames & Hannington & 415407 & 196085 & Cricklade & 39040 & 1.44 & 0.67 & $1961-2005$ & $\sim 10 \mathrm{~km} \mathrm{D}$ of gauge \\
\hline Thames & Swinford & 444307 & 208615 & Eynsham & 39008 & 14.8 & 0.67 & $1951-2001$ & \\
\hline Thames & Wallingford & 461045 & 189467 & Day's Lock & 39002 & 28.3 & 0.64 & $1938-2002$ & $\sim 7 \mathrm{~km} \mathrm{D}$ of gauge, $\sim 6 \mathrm{~km} \mathrm{D}$ of Thame confl. \\
\hline Thames & Sonning & 475500 & 175780 & Reading & 39130 & 37.5 & 0.66 & $1992-2005$ & $\sim 5 \mathrm{~km} \mathrm{D}$ of gauge, $\sim 4 \mathrm{~km} \mathrm{D}$ of Kennet confl. \\
\hline Thames & Runnymede & 500567 & 172352 & Bray* & 39009 & 58.2 & 0.70 & 1959-1982 & $\sim 15 \mathrm{~km} \mathrm{D}$ of gauge, $\sim 14 \mathrm{~km} \mathrm{D}$ of Cut confl. \\
\hline
\end{tabular}

NGR - National grid reference

EA no. - Environment Agency gauging station number

BFI - Baseflow index

D - downstream

U - upstream

*Not a primary gauging station owing to leakage, flows indicative only (Marsh and Hannaford, 2008) 


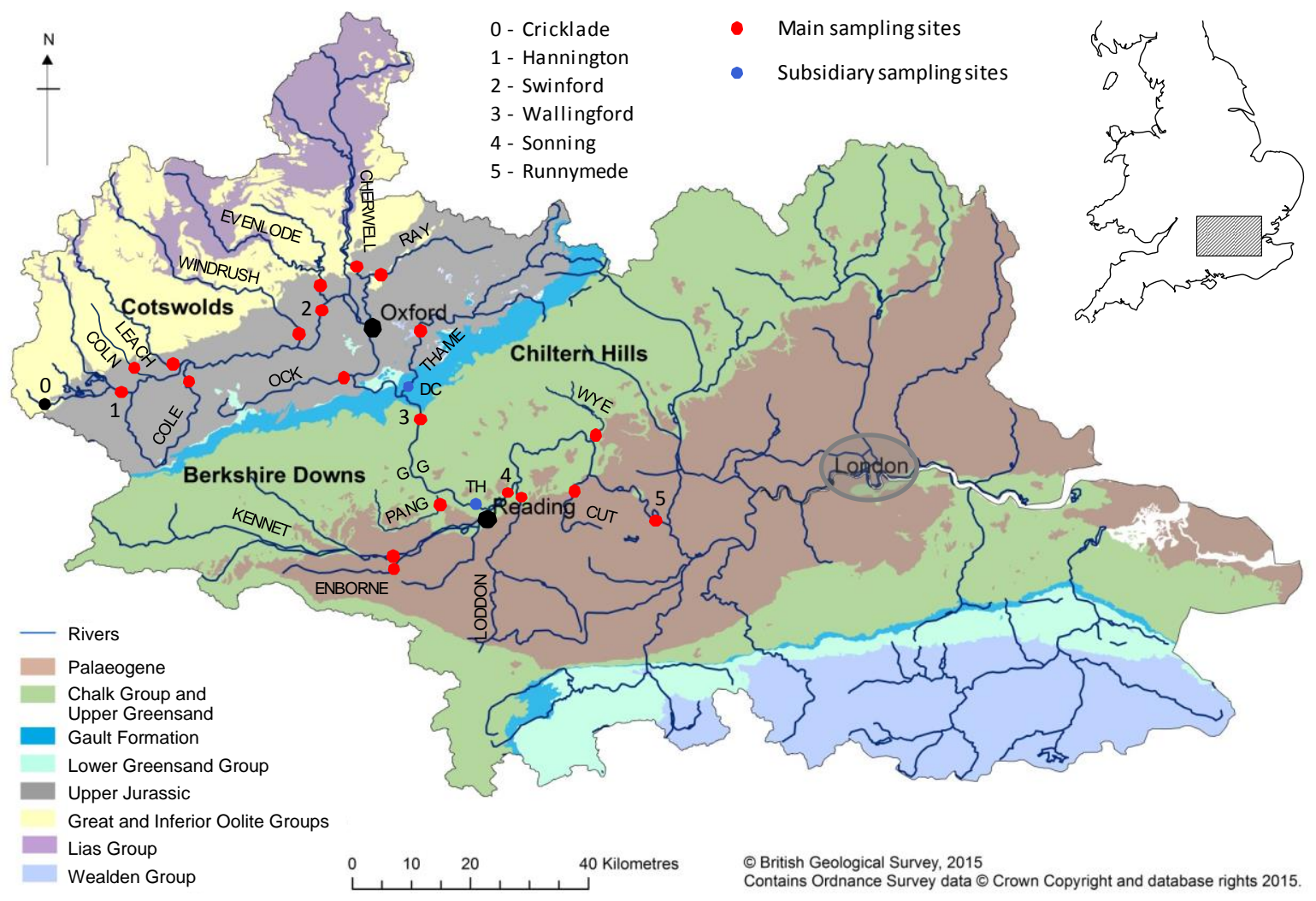

Figure 1. Map of the Thames basin with bedrock geology, river network and sampling points. Main carbonate formations shown in green or yellow. The upper Thames is defined here as the river network above Runnymede (sampling point 5). DC - Dorchester, GG Goring gap, $\mathrm{TH}$ - Tilehurst. 




Figure 2. Delta plot of monthly cumulative rainfall and River Thames monthly spot samples collected at Wallingford for the years 2003-2012. Regression equations and correlation coefficients are shown for both data series. The global meteoric water line (GMWL) is shown for comparison. 



Figure 3. Box plots for $\delta^{18} \mathrm{O}_{\mathrm{p}}$ and $\delta^{18} \mathrm{O}_{\mathrm{r}}$ at Wallingford for inter-annual (a,c) and seasonal (b,d) means over the period 2003-2012. Also shown are the respective rainfall amounts $(a, b)$, and river flows expressed in terms of mean daily flow (MDF) (c,d). The mean rainfall curve from Fig. 3b (dashed line) is also plotted on (d) for comparison. 



Figure 4. Delta plots of samples collected quarterly from October 2011 to April 2013 from the main tributaries in the upper Thames basin. Shown on each plot is the Wallingford meteoric line (equation shown on the plot for the Coln). 


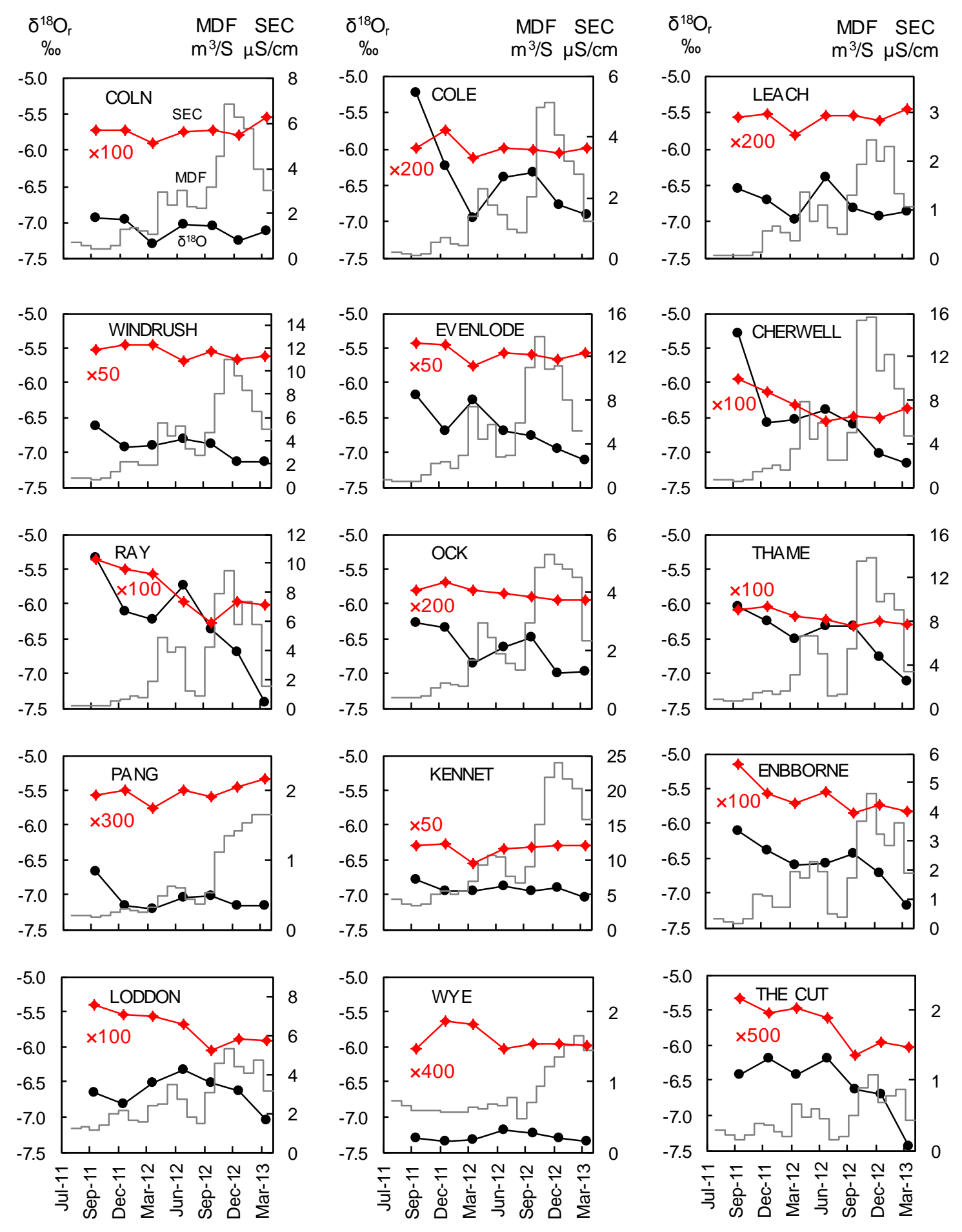

Figure 5. Values of $\delta^{18} \mathrm{O}_{\mathrm{r}}$ (in \%) from the October 2011-April 2013 quarterly sampling of the upper Thames tributaries compared to monthly mean daily flow (MDF, in $\mathrm{m}^{3} / \mathrm{S}$ ). Quarterly values of SEC (specific electrical conductivity) are also shown (in red) for comparison, with multiplication factor to give results in $\mu \mathrm{S} / \mathrm{cm}$. 

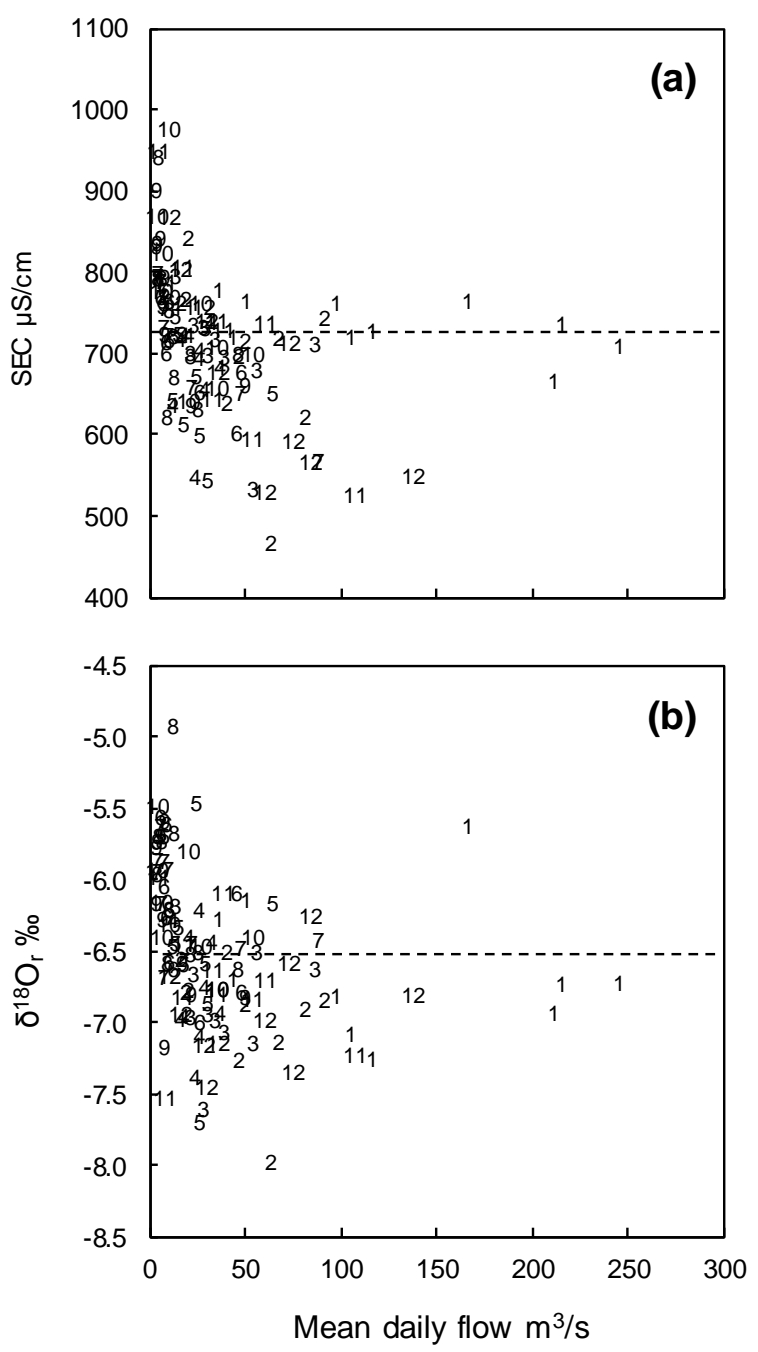

Figure 6. Plots of values from monthly spot samples from the Thames at Wallingford for (a) SEC and (b) $\delta^{18} \mathrm{O}_{\mathrm{r}}$ versus mean daily flow (MDF) averaged for the whole month. Data points are represented by the number of the month (January - 1, February - 2, etc.). Dashed lines indicate the 10-year median values. 

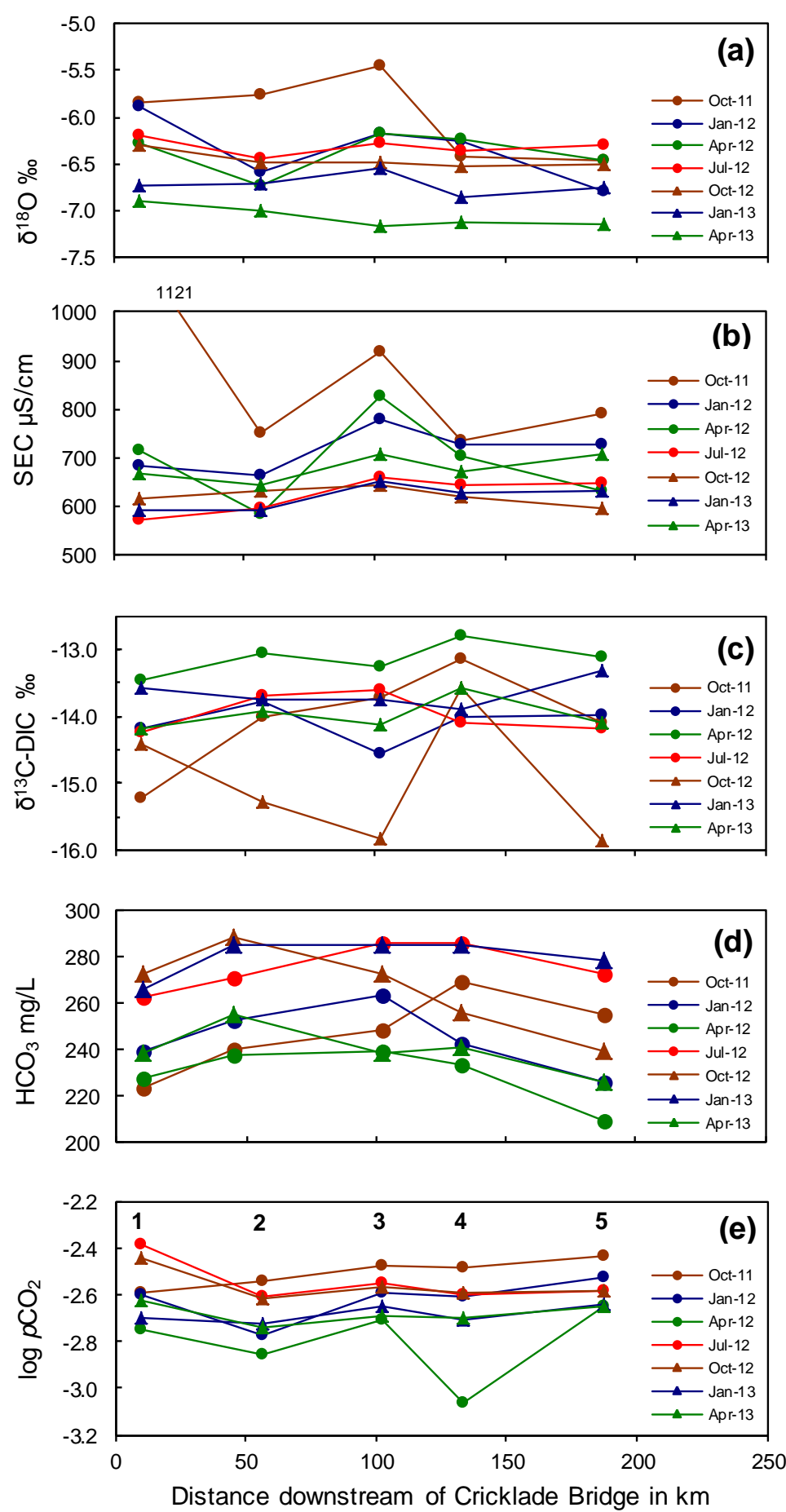

Figure 7. Plots of (a) $\delta^{18} \mathrm{O}$, (b) $\delta^{13} \mathrm{C}$-DIC, (c) alkalinity, (d) $p \mathrm{CO}_{2}$ and (e) SEC (specific electrical conductivity) for River Thames sampling sites over the quarterly monitoring period Oct 2011 to April 2013. Sites are: 1 - Hannington, 2 - Swinford, 3 - Wallingford, 4 Sonning, 5 - Runnymede. Refer to Figure 1 for locations. 

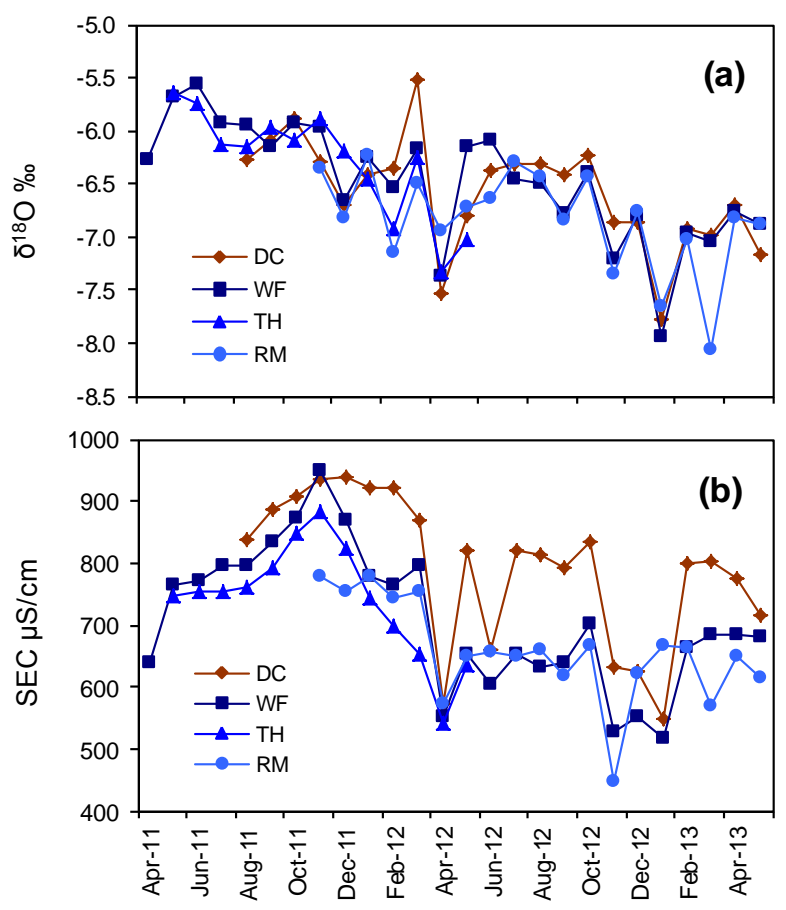

Figure 8. Comparison of monthly spot samples for (a) $\delta^{18} \mathrm{O}$ and (b) SEC (specific electrical conductivity) from the River Thame at Dorchester (DC), and the River Thames at Wallingford (WF), Tilehurst (TH) and Runnymede (RM). Refer to Figure 1 for locations. 

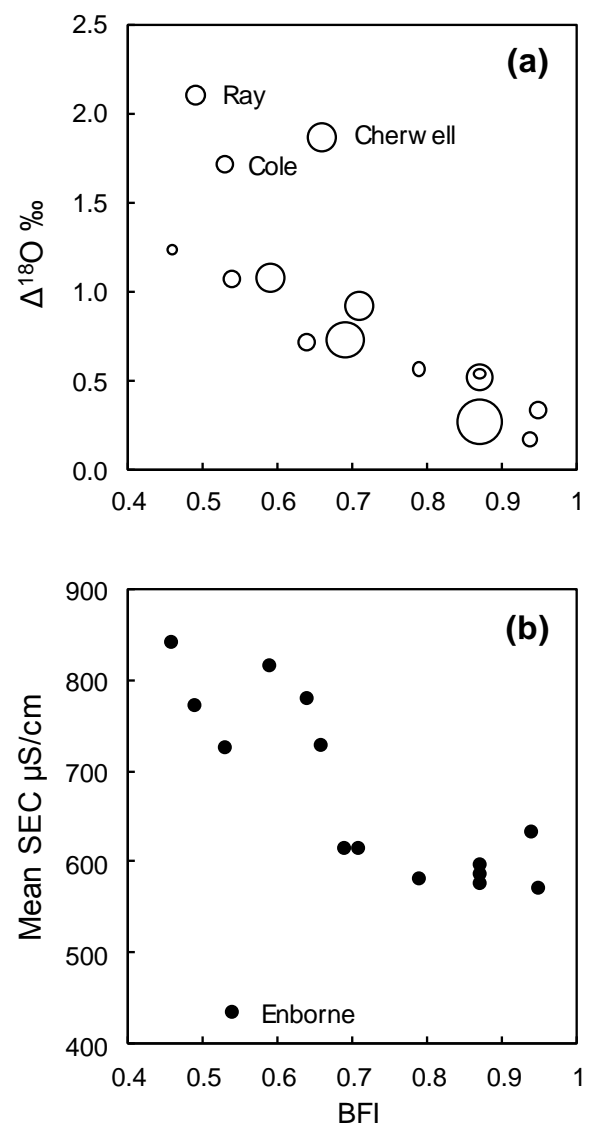

Figure 9. Plot of baseflow index (BFI, Table 1) versus (a) total range of $\delta^{18} \mathrm{O}$ values measured in each of the upper Thames tributaries during quarterly sampling October 2011April 2013 (symbol area proportional to mean flow in each tributary, Table 1), (b) mean specific electrical conductivity (SEC) from the quarterly sampling. Exceptions to the general trends are identified. 


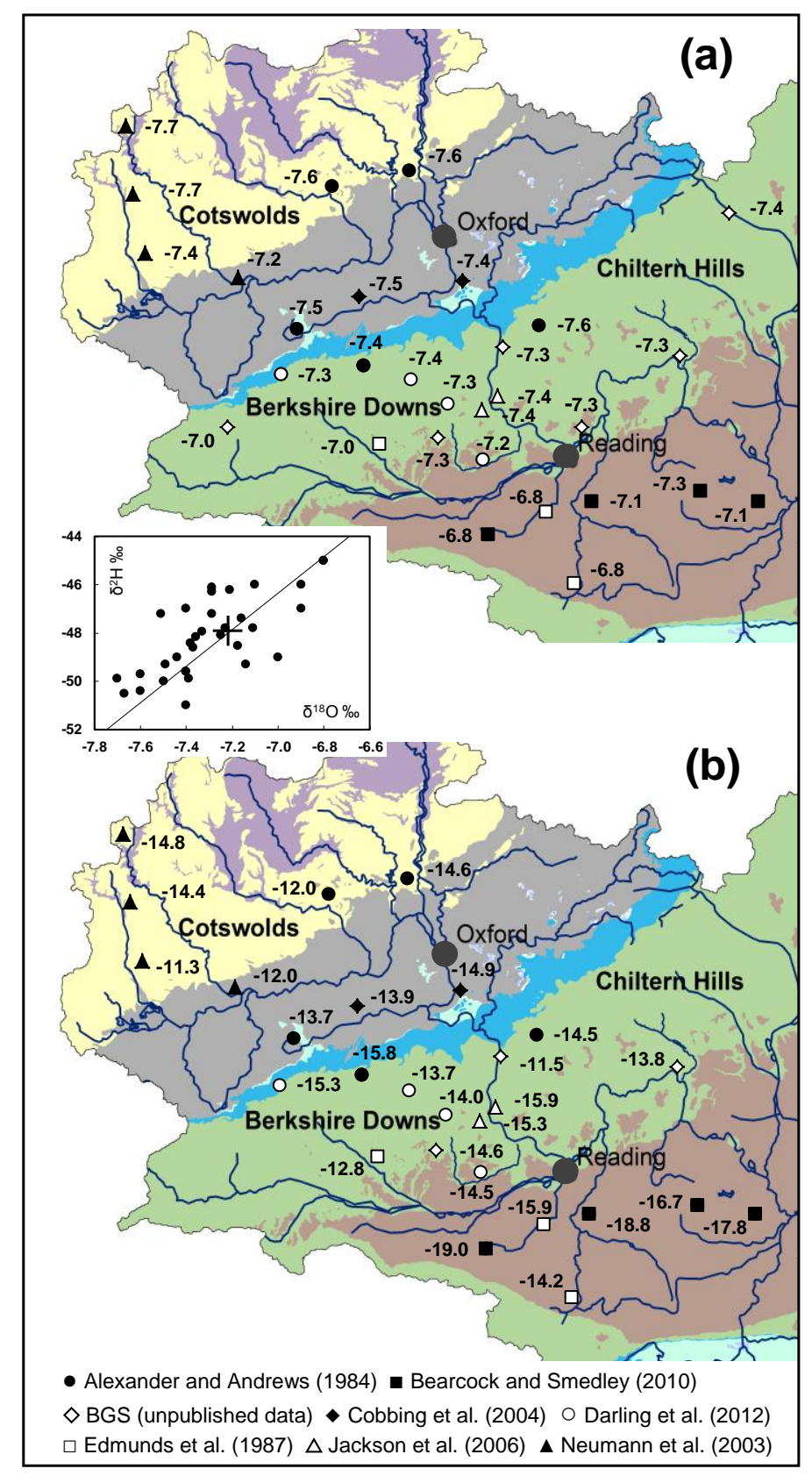

Figure 10. Maps showing regional distributions of (a) $\delta^{18} \mathrm{O}$ and (b) $\delta^{13} \mathrm{C}$-DIC in groundwaters of the upper Thames basin. Data sources as indicated. Geological legend and map copyrights as for Figure 1. Inset: delta-plot of groundwater data from the same sites, shown in relation to the Wallingford meteoric line (cross indicates the 2003-2012 weighted mean values for rainfall at Wallingford). 

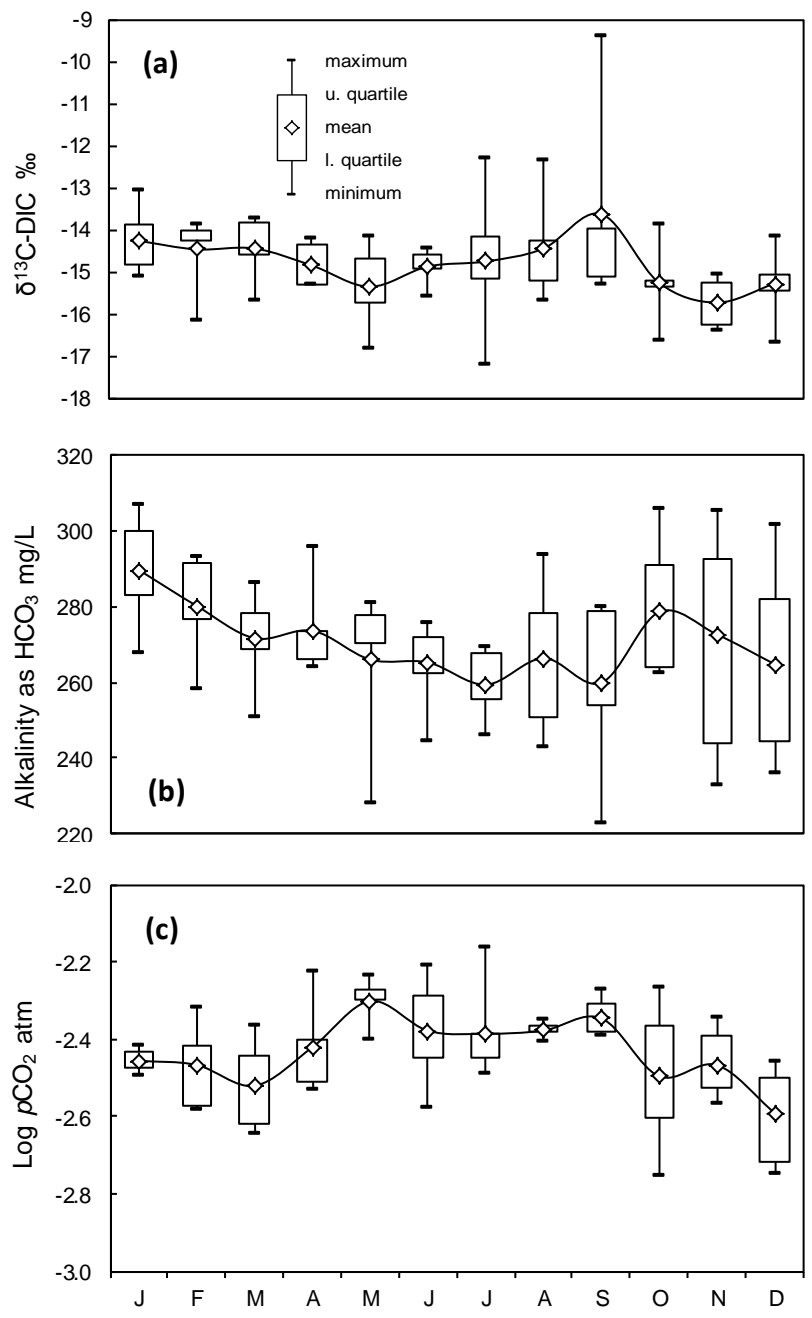

Figure 11. Box plots for monthly spot samples from the Thames at Wallingford for (a) $\delta^{13} \mathrm{C}$-DIC, (b) alkalinity and (c) $p \mathrm{CO}_{2}$, by monthly mean over the period 2003-2007. 

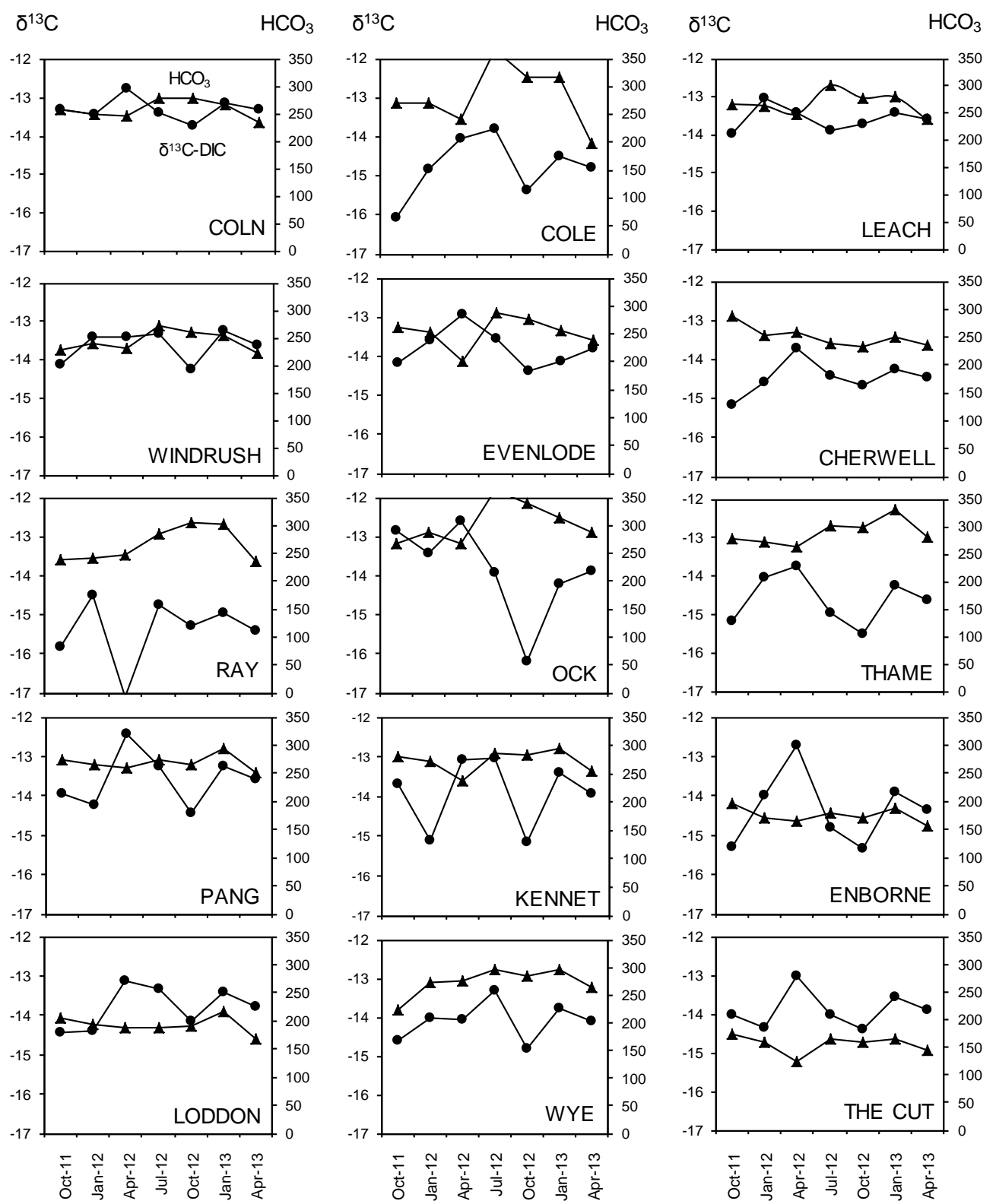

Figure 12. Values of $\delta^{13} \mathrm{C}$-DIC (in \%o) and alkalinity as $\mathrm{HCO}_{3}$ (in $\mathrm{mg} / \mathrm{L}$ ) from quarterly sampling of the upper Thames tributaries, October 2011-April 2013. 
Table S1. Values of $\delta^{18} \mathrm{O}, \delta^{2} \mathrm{H}$ and amount for monthly rainfall samples collected at Wallingford between January 2003 and May 2013.

\begin{tabular}{|c|c|c|c|}
\hline Month & $\begin{array}{c}\delta^{18} \mathrm{O} \\
\% 0\end{array}$ & $\begin{array}{c}\delta^{2} \mathbf{H} \\
\% 0\end{array}$ & $\begin{array}{c}\text { Amount } \\
\text { mm }\end{array}$ \\
\hline Jan-03 & -10.15 & -66.8 & 78 \\
\hline Feb-03 & -9.20 & -58.1 & 32 \\
\hline Mar-03 & -8.15 & -50.1 & 20 \\
\hline Apr-03 & -6.82 & -39.4 & 33 \\
\hline May-03 & -3.73 & -22.0 & 32 \\
\hline Jun-03 & -4.41 & -25.3 & 48 \\
\hline Jul-03 & -6.08 & -34.1 & 37 \\
\hline Aug-03 & -2.93 & -11.7 & 10 \\
\hline Sep-03 & -5.98 & -40.5 & 22 \\
\hline Oct-03 & -10.36 & -69.9 & 36 \\
\hline Nov-03 & -10.09 & -70.2 & 104 \\
\hline Dec-03 & -9.00 & -55.6 & 42 \\
\hline Jan-04 & -8.75 & -62.7 & 80 \\
\hline Feb-04 & -5.67 & -31.6 & 29 \\
\hline Mar-04 & -8.42 & -57.7 & 46 \\
\hline Apr-04 & -7.60 & -49.2 & 67 \\
\hline May-04 & -5.33 & -32.3 & 49 \\
\hline Jun-04 & -6.10 & -37.3 & 22 \\
\hline \multicolumn{4}{|l|}{ Jul-04 } \\
\hline Aug-04 & -6.95 & -46.1 & 133 \\
\hline Sep-04 & -3.52 & -18.8 & 22 \\
\hline Oct-04 & -7.15 & -42.6 & 101 \\
\hline Nov-04 & -6.76 & -38.3 & 30 \\
\hline Dec-04 & -11.09 & -76.9 & 40 \\
\hline Jan-05 & -3.97 & -27.3 & 15 \\
\hline Feb-05 & -7.53 & -47.2 & 16 \\
\hline Mar-05 & -6.10 & -45.4 & 39 \\
\hline Apr-05 & -4.77 & -36.6 & 45 \\
\hline May-05 & -2.81 & -17.4 & 21 \\
\hline Jun-05 & -3.87 & -23.1 & 31 \\
\hline Jul-05 & -6.90 & -48.3 & 40 \\
\hline Aug-05 & -4.55 & -31.6 & 36 \\
\hline Sep-05 & -5.23 & -29.8 & 53 \\
\hline Oct-05 & -5.78 & -37.6 & 50 \\
\hline Nov-05 & -5.99 & -36.0 & 43 \\
\hline Dec-05 & -9.83 & -66.3 & 66 \\
\hline Jan-06 & -7.89 & -48.8 & 17 \\
\hline Feb-06 & -8.46 & -58.6 & 34 \\
\hline Mar-06 & -5.89 & -39.1 & 31 \\
\hline Apr-06 & -5.25 & -38.2 & 18 \\
\hline Мay-06 & -7.65 & -47.9 & 105 \\
\hline Jun-06 & -1.99 & -2.8 & 7 \\
\hline Jul-06 & -4.26 & -21.1 & 46 \\
\hline Aug-06 & -6.92 & -39.6 & 45 \\
\hline Sep-06 & -10.89 & -74.4 & 52 \\
\hline Oct-06 & -6.10 & -36.2 & 114 \\
\hline Nov-06 & -8.77 & -55.7 & 69 \\
\hline Dec-06 & -5.65 & -30.2 & 71 \\
\hline
\end{tabular}

\begin{tabular}{|c|c|c|c|}
\hline Month & $\begin{array}{c}\delta^{18} \mathrm{O} \\
\% \text { o }\end{array}$ & $\begin{array}{c}\delta^{2} H \\
\% 0 \\
\end{array}$ & $\begin{array}{c}\text { Amount } \\
\text { mm }\end{array}$ \\
\hline Jan-07 & -5.89 & -37.0 & 69 \\
\hline Feb-07 & -9.44 & -64.9 & 13 \\
\hline Mar-07 & -5.97 & -41.6 & 41 \\
\hline Apr-07 & -0.29 & -8.6 & 1 \\
\hline Мay-07 & -8.45 & -59.6 & 125 \\
\hline Jun-07 & -8.35 & -62.2 & 85 \\
\hline Jul-07 & -6.04 & -38.5 & 97 \\
\hline Aug-07 & -6.44 & -45.7 & 34 \\
\hline Sep-07 & -5.52 & -34.6 & 34 \\
\hline Oct-07 & -5.60 & -30.6 & 43 \\
\hline Nov-07 & -9.81 & -64.3 & 54 \\
\hline Dec-07 & -8.08 & -50.5 & 24 \\
\hline Jan-08 & -9.69 & -69.2 & 76 \\
\hline Feb-08 & -6.51 & -43.3 & 15 \\
\hline Mar-08 & -6.62 & -39.6 & 68 \\
\hline Apr-08 & -7.61 & -50.9 & 45 \\
\hline Мay-08 & -6.27 & -38.5 & 78 \\
\hline Jun-08 & -7.68 & -49.3 & 65 \\
\hline Jul-08 & -6.05 & -33.2 & 71 \\
\hline Aug-08 & -4.72 & -32.3 & 70 \\
\hline Sep-08 & -7.12 & -46.9 & 62 \\
\hline Oct-08 & -7.22 & -42.9 & 44 \\
\hline Nov-08 & -8.64 & -54.5 & 78 \\
\hline Dec-08 & -12.76 & -91.8 & 34 \\
\hline Jan-09 & -9.19 & -69.1 & 46 \\
\hline Feb-09 & -12.62 & -96.4 & 56 \\
\hline Mar-09 & -9.72 & -74.6 & 18 \\
\hline Apr-09 & -5.79 & -42.8 & 28 \\
\hline Мay-09 & -5.10 & -27.6 & 36 \\
\hline Jun-09 & -4.38 & -23.0 & 26 \\
\hline Jul-09 & -6.59 & -46.9 & 79 \\
\hline Aug-09 & -4.92 & -33.6 & 34 \\
\hline Sep-09 & -5.76 & -38.0 & 11 \\
\hline Oct-09 & -5.00 & -29.5 & 52 \\
\hline Nov-09 & -8.33 & -54.7 & 107 \\
\hline Dec-09 & -9.04 & -59.9 & 72 \\
\hline Jan-10 & -12.22 & -88.2 & 63 \\
\hline Feb-10 & -10.79 & -73.1 & 58 \\
\hline Mar-10 & -6.35 & -44.2 & 36 \\
\hline Apr-10 & -4.64 & -28.2 & 23 \\
\hline May-10 & -4.92 & -30.2 & 28 \\
\hline Jun-10 & -4.88 & -36.1 & 16 \\
\hline Jul-10 & -3.61 & -28.7 & 19 \\
\hline Aug-10 & -6.62 & -46.9 & 110 \\
\hline Sep-10 & -6.66 & -46.1 & 42 \\
\hline Oct-10 & -7.22 & -40.7 & 42 \\
\hline Nov-10 & -7.97 & -54.6 & 46 \\
\hline Dec-10 & -9.71 & -67.1 & 22 \\
\hline
\end{tabular}

\begin{tabular}{|c|c|c|c|}
\hline Month & $\begin{array}{c}\delta^{18} \mathrm{O} \\
\% \text { o }\end{array}$ & $\begin{array}{c}\delta^{2} H \\
\% \text { o }\end{array}$ & $\begin{array}{c}\text { Amount } \\
\mathbf{m m}\end{array}$ \\
\hline Jan-11 & -9.89 & -71.3 & 77 \\
\hline Feb-11 & -7.19 & -48.3 & 38 \\
\hline Mar-11 & -6.72 & -48.2 & 9 \\
\hline Apr-11 & 0.42 & 9.8 & 2 \\
\hline May-11 & -3.39 & -22.1 & 11 \\
\hline Jun-11 & -4.85 & -32.9 & 42 \\
\hline Jul-11 & -4.98 & -34.4 & 35 \\
\hline Aug-11 & -5.26 & -38.5 & 64 \\
\hline Sep-11 & -3.64 & -24.2 & 47 \\
\hline Oct-11 & -4.34 & -19.4 & 22 \\
\hline Nov-11 & -5.29 & -28.6 & 26 \\
\hline Dec-11 & -10.31 & -67.6 & 62 \\
\hline Jan-12 & -7.38 & -48.2 & 33 \\
\hline Feb-12 & -11.18 & -78.9 & 15 \\
\hline Mar-12 & -12.10 & -88.5 & 21 \\
\hline Apr-12 & -5.76 & -40.0 & 111 \\
\hline May-12 & -6.50 & -41.8 & 45 \\
\hline Jun-12 & -6.05 & -40.7 & 118 \\
\hline Jul-12 & -6.28 & -46.1 & 87 \\
\hline Aug-12 & -6.11 & -43.0 & 68 \\
\hline Sep-12 & -7.25 & -47.4 & 27 \\
\hline Oct-12 & -6.26 & -41.2 & 97 \\
\hline Nov-12 & -8.82 & -58.7 & 79 \\
\hline Dec-12 & -8.52 & -61.2 & 96 \\
\hline Jan-13 & -8.95 & -61.3 & 54 \\
\hline Feb-13 & -11.78 & -85.8 & 36 \\
\hline Mar-13 & -10.43 & -73.7 & 87 \\
\hline Apr-13 & -8.03 & -58.5 & 20 \\
\hline May-13 & -7.60 & -51.6 & 57 \\
\hline
\end{tabular}


Table S2. Values of $\delta^{18} \mathrm{O}, \delta^{2} \mathrm{H}$, temperature and specific electrical conductivity for end-ofmonth spot samples collected from the River Thames at Wallingford 2003-2012. Also included is mean daily flow for the whole month calculated from flows measured by the Environment Agency at Day's Lock (Thames, Stn. 39002) and Wheatley (Thame, Stn. 39105).

\begin{tabular}{|c|c|c|c|c|c|}
\hline Month & $\begin{array}{c}\delta^{18} \mathrm{O} \\
\% 0 \\
\end{array}$ & $\begin{array}{l}\delta^{2} H \\
\% 0 \\
\end{array}$ & $\begin{array}{c}\text { Temp } \\
{ }^{\circ} \mathrm{C} \\
\end{array}$ & $\begin{array}{c}\text { SEC } \\
\mu \mathrm{S} / \mathrm{cm}\end{array}$ & $\begin{array}{r}\text { MDF } \\
\mathrm{m}^{3} / \mathrm{s} \\
\end{array}$ \\
\hline Jan-2003 & -6.71 & -47.8 & & 711 & 245 \\
\hline Feb-2003 & -6.86 & -49.3 & & 717 & 50.4 \\
\hline Mar-2003 & -7.05 & -45.6 & & 697 & 39.3 \\
\hline Apr-2003 & -6.96 & -45.6 & & 719 & 16.6 \\
\hline May-2003 & -6.43 & -43.0 & & 748 & 13.9 \\
\hline Jun-2003 & -6.03 & -40.8 & & 779 & 8.0 \\
\hline Jul-2003 & -5.61 & -41.7 & & 791 & 6.1 \\
\hline Aug-2003 & -4.91 & -33.5 & & 943 & 5.0 \\
\hline Sep-2003 & -5.76 & -37.3 & & 902 & 4.0 \\
\hline Oct-2003 & -5.47 & -38.2 & & 980 & 4.0 \\
\hline Nov-2003 & -7.51 & -53.2 & & 790 & 7.9 \\
\hline Dec-2003 & -7.14 & -48.0 & & 759 & 28.1 \\
\hline Jan-2004 & -7.07 & -46.7 & & 722 & 105 \\
\hline Feb-2004 & -7.12 & -44.9 & & 721 & 67.9 \\
\hline Mar-2004 & -7.59 & -51.5 & & 734 & 28.6 \\
\hline Apr-2004 & -7.08 & -45.3 & & 706 & 26.4 \\
\hline May-2004 & -6.57 & -43.9 & & 733 & 29.6 \\
\hline Jun-2004 & -6.20 & -41.7 & & 766 & 10.6 \\
\hline Jul-2004 & -5.86 & -41.6 & & 757 & 8.1 \\
\hline Aug-2004 & -5.66 & -40.5 & & 673 & 13.3 \\
\hline Sep-2004 & -5.58 & -39.3 & & 795 & 8.2 \\
\hline Oct-2004 & -6.75 & -45.9 & & 659 & 35.1 \\
\hline Nov-2004 & -6.08 & -41.6 & & 730 & 38.3 \\
\hline Dec-2004 & -7.13 & -46.1 & & 679 & 35.6 \\
\hline Jan-2005 & -6.13 & -42.0 & & 766 & 50.8 \\
\hline Feb-2005 & -6.76 & -45.4 & & 843 & 20.7 \\
\hline Mar-2005 & -6.95 & -43.6 & & 702 & 21.8 \\
\hline Apr-2005 & -6.42 & -41.9 & & 740 & 32.9 \\
\hline May-2005 & -6.32 & -41.0 & & 725 & 15.5 \\
\hline Jun-2005 & -5.60 & -37.5 & & 702 & 9.2 \\
\hline Jul-2005 & -6.15 & -39.6 & 18.9 & 771 & 6.8 \\
\hline Aug-2005 & -5.68 & -39.3 & 19.8 & 794 & 5.1 \\
\hline Sep-2005 & -5.72 & -36.3 & 15.0 & 837 & 4.4 \\
\hline Oct-2005 & -6.39 & -43.3 & 14.4 & 825 & 6.2 \\
\hline Nov-2005 & -6.81 & -44.8 & 4.6 & 808 & 17.2 \\
\hline Dec-2005 & -7.44 & -48.8 & 4.1 & 742 & 29.6 \\
\hline Jan-2006 & -6.68 & -42.8 & 3.4 & 722 & 43.8 \\
\hline Feb-2006 & -6.77 & -42.9 & 5.1 & 769 & 19.6 \\
\hline Mar-2006 & -6.65 & -44.1 & 10.0 & 736 & 23.4 \\
\hline Apr-2006 & -6.20 & -41.7 & 12.7 & 696 & 26.2 \\
\hline May-2006 & -5.45 & -36.1 & 14.2 & 674 & 24.9 \\
\hline Jun-2006 & -6.61 & -42.1 & 20.0 & 723 & 12.9 \\
\hline Jul-2006 & -5.91 & -36.5 & 23.2 & 724 & 10.2 \\
\hline Aug-2006 & -5.72 & -38.5 & 18.3 & 794 & 6.8 \\
\hline Sep-2006 & -7.16 & -49.7 & 17.2 & 726 & 8.1 \\
\hline Oct-2006 & -6.75 & -45.6 & 11.7 & 710 & 35.1 \\
\hline Nov-2006 & -6.82 & -46.2 & 8.5 & 596 & 53.5 \\
\hline Dec-2006 & -6.24 & -40.0 & 5.7 & 568 & 83.9 \\
\hline Jan-2007 & -6.72 & -40.9 & 10.1 & 738 & 215 \\
\hline Feb-2007 & -6.89 & -47.0 & 8.2 & 623 & 81.8 \\
\hline Mar-2007 & -6.61 & -42.7 & 9.4 & 713 & 86.8 \\
\hline Apr-2007 & -6.39 & -41.6 & 16.1 & 724 & 21.0 \\
\hline May-2007 & -7.68 & -49.5 & 13.9 & 602 & 26.6 \\
\hline Jun-2007 & -6.98 & -46.9 & 16.6 & 654 & 26.7 \\
\hline Jul-2007 & -6.41 & -41.3 & 18.2 & 570 & 88.6 \\
\hline Aug-2007 & -6.61 & -41.8 & 16.7 & 701 & 46.6 \\
\hline Sep-2007 & -6.57 & -42.8 & 12.8 & 725 & 17.5 \\
\hline Oct-2007 & -6.45 & -41.1 & 11.5 & 764 & 26.6 \\
\hline Nov-2007 & -6.79 & -45.4 & 8.1 & 742 & 34.8 \\
\hline Dec-2007 & -6.57 & -40.2 & 7.2 & 714 & 72.6 \\
\hline
\end{tabular}

\begin{tabular}{|c|c|c|c|c|c|}
\hline Month & $\begin{array}{c}\delta^{18} O \\
\% 0 \\
\end{array}$ & $\begin{array}{l}\delta^{2} \mathrm{H} \\
\% 0 \\
\end{array}$ & $\begin{array}{c}\text { Temp } \\
{ }^{\circ} \mathrm{C} \\
\end{array}$ & $\begin{array}{c}\text { SEC } \\
\mu \mathrm{S} / \mathrm{cm}\end{array}$ & $\begin{array}{r}\text { MDF } \\
\mathbf{m}^{3} / \mathrm{s} \\
\end{array}$ \\
\hline Jan-2008 & -6.92 & -45.0 & 8.8 & 668 & 211 \\
\hline Feb-2008 & -7.25 & -46.1 & 7.7 & 698 & 47.1 \\
\hline Mar-2008 & -6.49 & -40.4 & 9.1 & 681 & 56.4 \\
\hline Apr-2008 & -6.74 & -45.7 & 11.5 & 658 & 29.0 \\
\hline May-2008 & -6.85 & -45.9 & 14.8 & 546 & 30.7 \\
\hline Jun-2008 & -6.77 & -42.4 & 17.7 & 679 & 48.4 \\
\hline Jul-2008 & -6.43 & -40.1 & 20.7 & 661 & 22.5 \\
\hline Aug-2008 & -6.51 & -41.9 & 17.9 & 699 & 21.8 \\
\hline Sep-2008 & -6.81 & -43.0 & 13.5 & 663 & 50.3 \\
\hline Oct-2008 & -5.79 & -39.3 & 8.4 & 643 & 20.2 \\
\hline Nov-2008 & -6.69 & -45.8 & 5.7 & 739 & 60.3 \\
\hline Dec-2008 & -6.97 & -45.0 & 2.4 & 532 & 60.0 \\
\hline Jan-2009 & -6.80 & -46.2 & 3.0 & 764 & 97.8 \\
\hline Feb-2009 & -6.83 & -44.4 & 8.3 & 745 & 91.9 \\
\hline Mar-2009 & -6.97 & -44.9 & 9.3 & 719 & 34.7 \\
\hline Apr-2009 & -6.94 & -44.2 & 14.3 & 724 & 18.4 \\
\hline May-2009 & -6.45 & -43.0 & 18.6 & 644 & 12.5 \\
\hline Jun-2009 & -6.56 & -44.3 & 21.5 & 718 & 10.6 \\
\hline Jul-2009 & -6.67 & -44.2 & 18.1 & 734 & 7.9 \\
\hline Aug-2009 & -6.19 & -42.6 & 17.2 & 755 & 10.6 \\
\hline Sep-2009 & -5.68 & -40.2 & 14.6 & 843 & 6.2 \\
\hline Oct-2009 & -6.14 & -42.4 & 10.5 & 779 & 5.9 \\
\hline Nov-2009 & -6.62 & -45.5 & 7.3 & 646 & 32.6 \\
\hline Dec-2009 & -7.33 & -48.6 & 2.4 & 594 & 74.9 \\
\hline Jan-2010 & -5.61 & -43.9 & 3.2 & 766 & 167 \\
\hline Feb-2010 & -7.96 & -51.7 & 6.3 & 469 & 63.9 \\
\hline Mar-2010 & -7.13 & -46.3 & 8.7 & 535 & 54.5 \\
\hline Apr-2010 & -6.92 & -45.5 & 15.0 & 685 & 37.2 \\
\hline May-2010 & -6.58 & -46.3 & 16.5 & 615 & 18.3 \\
\hline Jun-2010 & -6.25 & -45.2 & 21.7 & 716 & 9.2 \\
\hline Jul-2010 & -5.85 & -41.9 & 21.1 & 801 & 4.6 \\
\hline Aug-2010 & -6.57 & -43.5 & 16.2 & 623 & 9.6 \\
\hline Sep-2010 & -6.26 & -43.4 & 14.2 & 759 & 7.1 \\
\hline Oct-2010 & -6.30 & -44.0 & 10.5 & 771 & 9.9 \\
\hline Nov-2010 & -6.44 & -46.1 & 1.4 & 758 & 17.6 \\
\hline Dec-2010 & -6.93 & -47.1 & 3.8 & 805 & 16.0 \\
\hline Jan-2011 & -7.24 & -47.9 & 3.0 & 730 & 117 \\
\hline Feb-2011 & -6.49 & -44.4 & & 640 & 40.8 \\
\hline Mar-2011 & -6.93 & -46.4 & & 700 & 30.8 \\
\hline Apr-2011 & -6.27 & -43.3 & 16.7 & 638 & 12.7 \\
\hline May-2011 & -5.68 & -42.3 & 16.0 & 764 & 8.0 \\
\hline Jun-2011 & -5.55 & -42.2 & 19.6 & 771 & 6.4 \\
\hline Jul-2011 & -5.93 & -42.2 & 21.1 & 797 & 4.8 \\
\hline Aug-2011 & -5.95 & -41.0 & 16.5 & 795 & 4.4 \\
\hline Sep-2011 & -6.15 & -40.1 & 19.4 & 834 & 4.0 \\
\hline Oct-2011 & -5.92 & -39.0 & 13.2 & 871 & 3.8 \\
\hline Nov-2011 & -5.97 & -39.3 & 8.9 & 950 & 4.5 \\
\hline Dec-2011 & -6.66 & -44.1 & 8.9 & 869 & 10.2 \\
\hline Jan-2012 & -6.26 & -43.4 & 5.2 & 780 & 36.4 \\
\hline Feb-2012 & -6.54 & -44.1 & 9.3 & 763 & 17.0 \\
\hline Mar-2012 & -6.17 & -42.5 & 12.8 & 796 & 13.9 \\
\hline Apr-2012 & -7.37 & -49.3 & 9.3 & 550 & 24.2 \\
\hline May-2012 & -6.15 & -43.6 & 19.5 & 653 & 64.8 \\
\hline Jun-2012 & -6.08 & -42.8 & 17.0 & 604 & 46.0 \\
\hline Jul-2012 & -6.46 & -43.3 & 17.2 & 653 & 48.1 \\
\hline Aug-2012 & -6.50 & -44.2 & 16.2 & 633 & 25.8 \\
\hline Sep-2012 & -6.78 & -47.0 & 12.5 & 638 & 22.2 \\
\hline Oct-2012 & -6.39 & -43.3 & 8.8 & 700 & 53.8 \\
\hline Nov-2012 & -7.22 & -48.1 & 3.8 & 528 & 107 \\
\hline Dec-2012 & -6.80 & -45.4 & 8.1 & 551 & 138 \\
\hline
\end{tabular}

SEC - specific electrical conductivity

MDF - mean daily flow 
Table S3. Values of $\delta^{18} \mathrm{O}, \delta^{2} \mathrm{H}$, temperature and specific electrical conductivity (SEC) for river water samples collected from the upper Thames basin on the dates indicated from sites shown on the map in Fig. 1. Samples collected along the Thames are prefixed by T-.

\begin{tabular}{|c|c|c|c|c|c|c|c|c|c|}
\hline River & $\begin{array}{c}\delta^{18} \mathrm{O} \\
\% \text { o } \\
\end{array}$ & $\begin{array}{c}\delta^{2} H \\
\% 0 \\
\end{array}$ & $\begin{array}{c}\text { Temp } \\
{ }^{\circ} \mathbf{C} \\
\end{array}$ & $\begin{array}{c}\text { SEC } \\
\mu \mathrm{S} / \mathrm{cm}\end{array}$ & River & $\begin{array}{c}\delta^{18} \mathrm{O} \\
\% \text { o } \\
\end{array}$ & $\begin{array}{c}\delta^{2} H \\
\% \text { o } \\
\end{array}$ & $\begin{array}{c}\text { Temp } \\
{ }^{\circ} \mathbf{C}\end{array}$ & $\begin{array}{c}\text { SEC } \\
\mu \mathrm{S} / \mathrm{cm} \\
\end{array}$ \\
\hline 17-18 Oct 2011 & & \multicolumn{8}{|c|}{ 17-18 Oct 2011 (contd.) } \\
\hline Coln & -6.95 & -44.4 & 10.2 & 570 & Kennet & -6.78 & -45.8 & 10.3 & 605 \\
\hline Cole & -5.23 & -37.7 & 10.1 & 731 & Enborne & -6.11 & -40.2 & 10.2 & 561 \\
\hline Leach & -6.54 & -43.3 & 10.4 & 579 & Loddon & -6.66 & -43.2 & 11.6 & 753 \\
\hline Windrush & -6.63 & -44.2 & 10.3 & 591 & Wye & -7.30 & -48.8 & 12.3 & 589 \\
\hline Evenlode & -6.19 & -41.6 & 10.1 & 663 & The Cut & -6.43 & -43.6 & 13.1 & 1085 \\
\hline Cherwell & -5.29 & -38.4 & 10.7 & 991 & T-Hannington & -5.84 & -39.1 & 11.8 & 1121 \\
\hline Ray & -5.33 & -37.6 & 10.6 & 1026 & T-Swinford & -5.76 & -39.9 & 12.3 & 751 \\
\hline Ock & -6.28 & -41.4 & 10.7 & 811 & T-Wallingford & -5.45 & -39.0 & 13.9 & 918 \\
\hline Thame & -6.04 & -41.2 & 10.8 & 906 & T-Sonning & -6.43 & -43.6 & 13.6 & 734 \\
\hline Pang & -6.67 & -45.3 & 9.1 & 575 & T-Runnymede & -6.47 & -45.4 & 14.3 & 790 \\
\hline $16 \operatorname{Jan} 2012$ & & \multicolumn{8}{|c|}{16 Jan 2012 (contd.) } \\
\hline Coln & -6.96 & -47.6 & 6.1 & 573 & Kennet & -6.94 & -44.4 & 3.2 & 619 \\
\hline Cole & -6.23 & -41.4 & 1.9 & 847 & Enborne & -6.39 & -42.7 & 2.2 & 465 \\
\hline Leach & -6.69 & -42.9 & 5.7 & 595 & Loddon & -6.81 & -46.9 & 3.8 & 704 \\
\hline Windrush & -6.93 & -47.8 & 2.7 & 611 & Wye & -7.34 & -49.1 & 7.7 & 742 \\
\hline Evenlode & -6.70 & -46.5 & 3.1 & 655 & The Cut & -6.20 & -42.9 & 4.8 & 973 \\
\hline Cherwell & -6.57 & -44.9 & 2.7 & 877 & T-Hannington & -5.89 & -40.1 & 4.9 & 683 \\
\hline Ray & -6.10 & -39.4 & 2.3 & 962 & T-Swinford & -6.58 & -44.8 & 4.2 & 663 \\
\hline Ock & -6.34 & -44.9 & 2.6 & 870 & T-Wallingford & -6.17 & -43.0 & 5.5 & 778 \\
\hline Thame & -6.24 & -43.0 & 2.4 & 929 & T-Sonning & -6.26 & -42.2 & 5.3 & 726 \\
\hline Pang & -7.17 & -48.4 & 3.4 & 602 & T-Runnymede & -6.80 & -44.8 & 6.3 & 726 \\
\hline 16 Apr 2012 & & \multicolumn{8}{|c|}{16 Apr 2012 (contd.) } \\
\hline Coln & -7.29 & -46.5 & 11.2 & 509 & Kennet & -6.95 & -44.3 & 10.5 & 477 \\
\hline Cole & -6.94 & -45.6 & 10.1 & 663 & Enborne & -6.61 & -43.2 & 7.9 & 431 \\
\hline Leach & -6.96 & -44.0 & 9.6 & 509 & Loddon & -6.51 & -44.5 & 10.0 & 693 \\
\hline Windrush & -6.90 & -43.3 & 9.8 & 615 & Wye & -7.32 & -47.6 & 9.3 & 725 \\
\hline Evenlode & -6.26 & -41.6 & 9.8 & 553 & The Cut & -6.42 & -43.8 & 9.3 & 1009 \\
\hline Cherwell & -6.52 & -44.2 & 9.6 & 750 & T-Hannington & -6.27 & -42.0 & 10.1 & 714 \\
\hline Ray & -6.22 & -42.3 & 8.6 & 928 & T-Swinford & -6.73 & -42.1 & 10.3 & 583 \\
\hline Ock & -6.85 & -44.6 & 10.1 & 810 & T-Wallingford & -6.18 & -42.6 & 11.0 & 828 \\
\hline Thame & -6.51 & -41.6 & 9.3 & 849 & T-Sonning & -6.24 & -41.6 & 10.8 & 704 \\
\hline Pang & -7.21 & -48.3 & 9.3 & 519 & T-Runnymede & -6.46 & -43.7 & 11.0 & 632 \\
\hline 23-24 Jul 2012 & & \multicolumn{8}{|c|}{ 23-24 Jul 2012 (contd.) } \\
\hline Coln & -7.02 & -46.6 & 15.1 & 563 & Kennet & -6.88 & -45.5 & 17.8 & 576 \\
\hline Cole & -6.39 & -42.9 & 18.8 & 732 & Enborne & -6.57 & -42.8 & 15.8 & 466 \\
\hline Leach & -6.39 & -42.7 & 15.5 & 588 & Loddon & -6.32 & -43.2 & 18.0 & 657 \\
\hline Windrush & -6.81 & -45.6 & 17.4 & 540 & Wye & -7.18 & -47.9 & 15.4 & 588 \\
\hline Evenlode & -6.70 & -44.8 & 17.1 & 618 & The Cut & -6.19 & -43.0 & 18.3 & 944 \\
\hline Cherwell & -6.40 & -43.8 & 18.4 & 611 & T-Hannington & -6.19 & -42.0 & 18.8 & 571 \\
\hline Ray & -5.73 & -40.4 & 17.8 & 729 & T-Swinford & -6.45 & -43.9 & 18.1 & 595 \\
\hline Ock & -6.62 & -45.1 & 17.9 & 787 & T-Wallingford & -6.27 & -42.2 & 18.5 & 658 \\
\hline Thame & -6.32 & -43.2 & 18.0 & 816 & T-Sonning & -6.36 & -42.8 & 18.0 & 642 \\
\hline Pang & -7.04 & -46.7 & 15.8 & 600 & T-Runnymede & -6.30 & -42.3 & 18.8 & 649 \\
\hline 22-23 Oct 2012 & & \multicolumn{8}{|c|}{ 22-23 Oct 2012 (contd.) } \\
\hline Coln & -7.06 & -46.1 & 11.2 & 570 & Kennet & -6.95 & -45.4 & 12.0 & 585 \\
\hline Cole & -6.33 & -41.7 & 12.1 & 711 & Enborne & -6.43 & -42.6 & 12.1 & 393 \\
\hline Leach & -6.82 & -44.3 & 11.5 & 588 & Loddon & -6.52 & -43.8 & 12.9 & 524 \\
\hline Windrush & -6.89 & -45.7 & 11.5 & 582 & Wye & -7.23 & -47.6 & 12.8 & 613 \\
\hline Evenlode & -6.77 & -44.9 & 11.5 & 613 & The Cut & -6.64 & -44.7 & 13.7 & 682 \\
\hline Cherwell & -6.61 & -44.3 & 11.6 & 652 & T-Hannington & -6.29 & -42.3 & 12.2 & 616 \\
\hline Ray & -6.36 & -40.4 & 12.3 & 589 & T-Swinford & -6.48 & -44.1 & 11.8 & 631 \\
\hline Ock & -6.49 & -42.1 & 12.3 & 763 & T-Wallingford & -6.48 & -42.8 & 12.1 & 644 \\
\hline Thame & -6.32 & -41.5 & 12.2 & 754 & T-Sonning & -6.52 & -41.4 & 12.1 & 619 \\
\hline Pang & -7.03 & -45.8 & 12.0 & 574 & T-Runnymede & -6.51 & -42.8 & 12.3 & 597 \\
\hline 14 Jan 2013 & & & & & $14 \operatorname{Jan} 2013$ & & & & \\
\hline Coln & -7.25 & -47.9 & 7.2 & 548 & Kennet & -6.92 & -45.6 & 6.0 & 598 \\
\hline Cole & -6.77 & -45.0 & 5.6 & 699 & Enborne & -6.72 & -43.9 & 5.3 & 421 \\
\hline Leach & -6.92 & -45.7 & 7.2 & 569 & Loddon & -6.63 & -44.0 & 5.7 & 575 \\
\hline Windrush & -7.15 & -47.0 & 5.6 & 548 & Wye & -7.30 & -48.6 & 7.4 & 616 \\
\hline Evenlode & -6.96 & -47.0 & 5.5 & 586 & The Cut & -6.70 & -44.9 & 5.5 & 774 \\
\hline Cherwell & -7.02 & -46.5 & 4.2 & 638 & T-Hannington & -6.73 & -45.1 & 5.5 & 592 \\
\hline Ray & -6.69 & -45.1 & 4.1 & 731 & T-Swinford & -6.72 & -45.7 & 4.9 & 590 \\
\hline Ock & -7.00 & -46.9 & 5.4 & 740 & T-Wallingford & -5.55 & -42.1 & 5.0 & 650 \\
\hline Thame & -6.76 & -44.4 & 4.2 & 793 & T-Sonning & -6.87 & -45.2 & 5.4 & 628 \\
\hline Pang & -7.16 & -47.5 & 6.0 & 611 & T-Runnymede & -6.76 & -45.3 & 5.9 & 630 \\
\hline 15 Apr 2013 & & & & & 15 Apr 2013 & & & & \\
\hline Coln & -7.12 & -47.3 & 12.3 & 627 & Kennet & -7.05 & -45.7 & 12.1 & 606 \\
\hline Cole & -6.89 & -46.2 & 11.8 & 722 & Enborne & -7.18 & -47.8 & 10.8 & 399 \\
\hline Leach & -6.85 & -45.0 & 11.1 & 616 & Loddon & -7.05 & -47.1 & 12.1 & 568 \\
\hline Windrush & -7.13 & -46.7 & 11.5 & 566 & Wye & -7.35 & -49.0 & 10.8 & 608 \\
\hline Evenlode & -7.11 & -47.8 & 10.5 & 620 & The Cut & -7.43 & -50.6 & 11.8 & 738 \\
\hline Cherwell & -7.16 & -49.0 & 11.1 & 731 & T-Hannington & -6.90 & -45.8 & 11.4 & 666 \\
\hline Ray & -7.43 & -51.9 & 10.7 & 716 & T-Swinford & -7.01 & -46.5 & 11.2 & 644 \\
\hline Ock & -6.97 & -45.7 & 11.8 & 746 & T-Wallingford & -7.16 & -48.8 & 11.2 & 707 \\
\hline Thame & -7.12 & -49.3 & 11.3 & 773 & T-Sonning & -7.13 & -47.8 & 11.0 & 670 \\
\hline Pang & -7.16 & -48.0 & 12.0 & 649 & T-Runnymede & -7.14 & -47.9 & 11.0 & 708 \\
\hline
\end{tabular}


Table S4. Results of end-of-month sampling of the River Thame at Dorchester (DC) and the River Thames at Wallingford (WF), Tilehurst (TH) and Runnymede (RM). Refer to Fig. 1 for locations.

\begin{tabular}{lcccc}
\hline Month & \multicolumn{4}{c}{$\boldsymbol{\delta}^{\mathbf{1 8}} \mathbf{\text { O }}$} \\
& DC & WF & TH & RM \\
\hline Apr-11 & - & -6.27 & - & - \\
May-11 & - & -5.68 & -5.65 & - \\
Jun-11 & - & -5.55 & -5.74 & - \\
Jul-11 & - & -5.93 & -6.12 & - \\
Aug-11 & -6.28 & -5.95 & -6.15 & - \\
Sep-11 & -6.08 & -6.15 & -5.96 & - \\
Oct-11 & -5.89 & -5.92 & -6.08 & - \\
Nov-11 & -6.29 & -5.97 & -5.89 & -6.35 \\
Dec-11 & -6.70 & -6.66 & -6.19 & -6.82 \\
Jan-12 & -6.41 & -6.26 & -6.46 & -6.24 \\
Feb-12 & -6.35 & -6.54 & -6.93 & -7.15 \\
Mar-12 & -5.52 & -6.17 & -6.26 & -6.50 \\
Apr-12 & -7.54 & -7.37 & -7.32 & -6.94 \\
May-12 & -6.80 & -6.15 & -7.02 & -6.71 \\
Jun-12 & -6.38 & -6.08 & - & -6.63 \\
Jul-12 & -6.31 & -6.46 & - & -6.30 \\
Aug-12 & -6.32 & -6.50 & - & -6.43 \\
Sep-12 & -6.41 & -6.78 & - & -6.84 \\
Oct-12 & -6.24 & -6.39 & - & -6.43 \\
Nov-12 & -6.87 & -7.22 & - & -7.35 \\
Dec-12 & -6.87 & -6.80 & - & -6.76 \\
Jan-13 & -7.78 & -7.94 & - & -7.65 \\
Feb-13 & -6.92 & -6.96 & - & -7.02 \\
Mar-13 & -6.98 & -7.05 & - & -8.06 \\
Apr-13 & -6.69 & -6.77 & - & -6.82 \\
May-13 & -7.16 & -6.89 & - & -6.88 \\
\hline & & & & \\
\hline
\end{tabular}

\begin{tabular}{cccc}
\hline \multicolumn{4}{c}{$\boldsymbol{\delta}^{\mathbf{2}} \mathbf{H} \%$} \\
$\mathbf{D C}$ & $\mathbf{W F}$ & $\mathbf{T H}$ & $\mathbf{R M}$ \\
\hline- & -43.3 & - & - \\
- & -42.3 & -42.9 & - \\
- & -42.2 & -41.3 & - \\
- & -42.2 & -42.4 & - \\
-43.2 & -41.0 & -40.1 & - \\
-41.7 & -40.1 & -39.1 & - \\
-41.6 & -39.0 & -40.5 & - \\
-41.6 & -39.3 & -40.1 & -40.4 \\
-46.1 & -44.1 & -41.7 & -43.7 \\
-45.0 & -43.4 & -44.8 & -44.4 \\
-46.3 & -44.1 & -45.9 & -46.5 \\
-43.5 & -42.5 & -43.9 & -45.2 \\
-49.7 & -49.3 & -48.0 & -47.2 \\
-46.4 & -43.6 & -47.1 & -43.2 \\
-43.2 & -42.8 & - & -44.0 \\
-43.5 & -43.3 & - & -42.3 \\
-43.3 & -44.2 & - & -43.5 \\
-42.9 & -47.0 & - & -45.8 \\
-42.4 & -43.3 & - & -43.4 \\
-45.4 & -48.1 & - & -49.8 \\
-45.3 & -45.4 & - & -45.4 \\
-52.3 & -53.2 & - & -51.2 \\
-45.5 & -46.9 & - & -46.1 \\
-45.9 & -47.5 & - & -56.2 \\
-44.3 & -45.2 & - & -46.0 \\
-47.9 & -46.4 & - & -46.4 \\
\hline & & &
\end{tabular}

\begin{tabular}{cccc}
\hline \multicolumn{4}{c}{$\boldsymbol{\delta}^{\mathbf{1 3}} \mathbf{C}-\mathrm{DIC} \% \mathbf{}$} \\
$\mathbf{D C}$ & $\mathbf{W F}$ & $\mathbf{T H}$ & $\mathbf{R M}$ \\
\hline & -13.5 & - & - \\
& -13.5 & - & - \\
& -13.8 & - & - \\
& -14.2 & - & - \\
-15.6 & -13.8 & - & - \\
-15.4 & -14.3 & - & - \\
-15.5 & -14.8 & - & - \\
-14.5 & -14.2 & - & -14.4 \\
-14.1 & -14.4 & - & -14.2 \\
-14.7 & -14.2 & - & -14.2 \\
-13.4 & -13.0 & - & -13.3 \\
-13.8 & -13.9 & - & -12.7 \\
-16.9 & -16.3 & - & -15.1 \\
-14.6 & -13.7 & - & -13.5 \\
-16.3 & -15.6 & - & -14.7 \\
-16.2 & -13.3 & - & -14.2 \\
-14.5 & -13.8 & - & -15.0 \\
-14.8 & -14.5 & - & -14.9 \\
-15.6 & -14.0 & - & -15.0 \\
-16.1 & -15.3 & - & -15.6 \\
-16.4 & -15.2 & - & -15.0 \\
-16.5 & -16.1 & - & -15.5 \\
-16.2 & -14.2 & - & -14.4 \\
-14.3 & -14.5 & - & -15.6 \\
-13.1 & -13.6 & - & -12.9 \\
-14.5 & -13.7 & - & -12.7 \\
\hline & & &
\end{tabular}

\begin{tabular}{cccc}
\hline \multicolumn{4}{c}{ SEC $\mathbf{~ m S / c m}$} \\
DC & WF & TH & RM \\
\hline- & 638 & & - \\
- & 764 & 746 & - \\
- & 771 & 755 & - \\
- & 797 & 754 & - \\
837 & 795 & 761 & - \\
886 & 834 & 791 & - \\
907 & 871 & 849 & - \\
935 & 950 & 883 & 780 \\
940 & 869 & 824 & 755 \\
920 & 780 & 745 & 779 \\
920 & 763 & 697 & 743 \\
868 & 796 & 653 & 756 \\
574 & 550 & 542 & 572 \\
820 & 653 & 636 & 649 \\
661 & 604 & & 656 \\
820 & 653 & & 649 \\
813 & 633 & & 659 \\
791 & 638 & & 617 \\
834 & 700 & & 666 \\
633 & 528 & & 447 \\
624 & 551 & & 623 \\
549 & 517 & & 667 \\
800 & 662 & & 663 \\
803 & 686 & & 570 \\
776 & 684 & & 651 \\
716 & 680 & & 613 \\
\hline & & &
\end{tabular}

\begin{tabular}{cccc}
\hline \multicolumn{4}{c}{ Temp ${ }^{\circ} \mathbf{C}$} \\
DC & WF & TH & RM \\
\hline & 16.7 & - & - \\
& 16.0 & - & - \\
& 19.6 & - & - \\
& 21.1 & - & - \\
15.2 & 16.5 & - & - \\
15.2 & 19.4 & - & - \\
11.3 & 13.2 & - & - \\
7.1 & 8.9 & - & 8.9 \\
8.8 & 8.9 & - & 8.1 \\
3.9 & 5.2 & - & 6.4 \\
9.3 & 9.3 & - & 9.2 \\
10.8 & 12.8 & - & 12.5 \\
10.6 & 9.3 & - & 11.3 \\
19.0 & 19.5 & - & 20.5 \\
16.0 & 17.0 & - & 17.4 \\
17.1 & 17.2 & - & 18.8 \\
17.6 & 16.2 & - & 18.1 \\
11.6 & 12.5 & - & 13.5 \\
8.6 & 8.8 & - & 10.5 \\
4.3 & 3.8 & - & 8.5 \\
8.7 & 8.1 & - & 8.6 \\
8.6 & 8.3 & - & 5.6 \\
5.4 & 5.0 & - & 5.6 \\
4.8 & 5.2 & - & 6.3 \\
11.0 & 11.7 & - & \\
11.5 & 12.9 & - & \\
\hline & & &
\end{tabular}


Table S5. Values of $\delta^{13} \mathrm{C}$-DIC, $\mathrm{pH}$ and alkalinity as $\mathrm{HCO}_{3}$ for end-of-month spot samples collected from the River Thames at Wallingford, 2003-2007.

\begin{tabular}{|c|c|c|c|c|c|c|c|}
\hline Month & $\begin{array}{c}\delta^{13} \mathrm{C}-\mathrm{DIC} \\
\% \text { o } \\
\end{array}$ & pH & $\begin{array}{c}\text { Alkalinity } \\
\mathrm{mg} / \mathrm{L}\end{array}$ & Month & $\begin{array}{c}\delta^{13} \mathrm{C}-\mathrm{DIC} \\
\% \text { o } \\
\end{array}$ & pH & $\begin{array}{c}\text { Alkalinity } \\
\text { mg/L }\end{array}$ \\
\hline Jan-2003 & -15.1 & 7.80 & 291 & Jul-2005 & -15.0 & 7.87 & 268 \\
\hline Feb-2003 & -14.0 & 7.83 & 291 & Aug-2005 & -14.2 & 7.81 & 267 \\
\hline Mar-2003 & -13.8 & 7.90 & 274 & Sep-2005 & -15.1 & 7.75 & 254 \\
\hline Apr-2003 & -14.3 & 7.77 & 264 & Oct-2005 & -15.4 & 7.76 & 264 \\
\hline May-2003 & -14.2 & 7.63 & 271 & Nov-2005 & -16.4 & 7.95 & 289 \\
\hline Jun-2003 & -14.8 & 7.61 & 263 & Dec-2005 & -15.5 & 7.87 & 282 \\
\hline Jul-2003 & -14.2 & 7.84 & 256 & Jan-2006 & -13.1 & 7.80 & 283 \\
\hline Aug-2003 & -12.4 & 7.81 & 278 & Feb-2006 & -14.3 & 7.94 & 277 \\
\hline Sep-2003 & -14.0 & 7.73 & 280 & Mar-2006 & -14.4 & 7.82 & 269 \\
\hline Oct-2003 & -13.9 & 7.98 & 270 & Apr-2006 & -14.2 & 7.90 & 269 \\
\hline Nov-2003 & -15.7 & 7.70 & 233 & May-2006 & -15.7 & 7.82 & 281 \\
\hline Dec-2003 & -15.1 & 8.03 & 244 & Jun-2006 & -14.6 & 7.81 & 272 \\
\hline Jan-2004 & -14.4 & 7.85 & 268 & Jul-2006 & -15.2 & 7.80 & 246 \\
\hline Feb-2004 & -14.1 & 7.79 & 281 & Aug-2006 & -14.8 & 7.73 & 243 \\
\hline Mar-2004 & -13.7 & 8.02 & 279 & Sep-2006 & -15.3 & 7.61 & 223 \\
\hline Apr-2004 & -15.3 & 7.60 & 266 & Oct-2006 & -15.2 & 7.91 & 291 \\
\hline May-2004 & -14.7 & 7.70 & 278 & Nov-2006 & -16.3 & 7.67 & 244 \\
\hline Jun-2004 & -14.5 & 7.99 & 272 & Dec-2006 & -16.7 & 7.76 & 236 \\
\hline Jul-2004 & -17.2 & 7.90 & 269 & Jan-2007 & -13.9 & 7.90 & 300 \\
\hline Aug-2004 & -15.7 & 7.80 & 251 & Feb-2007 & -16.2 & 7.67 & 258 \\
\hline Sep-2004 & -14.4 & 7.78 & 264 & Mar-2007 & -15.7 & 8.02 & 286 \\
\hline Oct-2004 & -16.6 & 7.64 & 263 & Apr-2007 & -15.1 & 7.99 & 274 \\
\hline Nov-2004 & -15.3 & 7.91 & 293 & May-2007 & -16.9 & 7.60 & 228 \\
\hline Dec-2004 & -15.1 & 7.87 & 260 & Jun-2007 & -14.9 & 7.87 & 276 \\
\hline Jan-2005 & -14.9 & 7.88 & 307 & Jul-2007 & -12.3 & 7.57 & 259 \\
\hline Feb-2005 & -13.9 & 7.97 & 293 & Aug-2007 & -15.2 & 7.83 & 294 \\
\hline Mar-2005 & -14.6 & 7.70 & 251 & Sep-2007 & -9.4 & 7.80 & 279 \\
\hline Apr-2005 & -15.3 & 7.85 & 296 & Oct-2007 & -15.2 & 8.19 & 306 \\
\hline May-2005 & -15.4 & 7.25 & 273 & Nov-2007 & -15.1 & 7.95 & 306 \\
\hline Jun-2005 & -15.6 & 7.65 & 244 & Dec-2007 & -14.2 & 8.16 & 302 \\
\hline
\end{tabular}

DIC - dissolved inorganic carbon 
Table S6. Values of $\delta^{13} \mathrm{C}$-DIC, $\mathrm{pH}$ and alkalinity as $\mathrm{HCO}_{3}$ for river water samples collected from the upper Thames basin on the dates indicated from sites shown on the map in Fig. 1. Samples collected along the Thames are prefixed by T-.

\begin{tabular}{|c|c|c|c|c|c|c|c|}
\hline River & $\begin{array}{c}\delta^{13} \mathrm{C} \text {-DIC } \\
\%\end{array}$ & pH & $\begin{array}{c}\text { Alkalinity } \\
\text { mg/L }\end{array}$ & River & $\begin{array}{c}\delta^{13} \mathrm{C}-\mathrm{DIC} \\
\% \\
\end{array}$ & pH & $\begin{array}{c}\text { Alkalinity } \\
\mathrm{mg} / \mathrm{L}\end{array}$ \\
\hline 17-18 Oct 2011 & & \multicolumn{6}{|c|}{ 17-18 Oct 2011 (contd.) } \\
\hline Coln & -13.3 & 8.03 & 258 & Kennet & -13.7 & 7.87 & 281 \\
\hline Cole & -16.1 & 7.88 & 270 & Enborne & -15.3 & 7.68 & 197 \\
\hline Leach & -14.0 & 7.90 & 266 & Loddon & -14.4 & 7.82 & 205 \\
\hline Windrush & -14.1 & 7.91 & 227 & Wye & -14.6 & 8.16 & 224 \\
\hline Evenlode & -14.2 & 7.86 & 262 & The Cut & -14.0 & 7.46 & 175 \\
\hline Cherwell & -15.2 & 7.78 & 287 & T-Hannington & -15.2 & 7.90 & 223 \\
\hline Ray & -15.8 & 7.31 & 239 & T-Swinford & -14.0 & 7.89 & 242 \\
\hline Ock & -12.9 & 7.98 & 268 & T-Wallingford & -13.7 & 7.84 & 248 \\
\hline Thame & -15.2 & 7.71 & 277 & T-Sonning & -13.1 & 7.88 & 269 \\
\hline Pang & -14.0 & 7.88 & 273 & T-Runnymede & -14.1 & 7.81 & 255 \\
\hline 16 Jan 2012 & & \multicolumn{6}{|c|}{16 Jan 2012 (contd.) } \\
\hline Coln & -13.4 & 7.99 & 252 & Kennet & -15.1 & 7.96 & 272 \\
\hline Cole & -14.8 & 8.02 & 270 & Enborne & -14.0 & 7.71 & 171 \\
\hline Leach & -13.1 & 8.02 & 263 & Loddon & -14.4 & 7.75 & 193 \\
\hline Windrush & -13.4 & 8.10 & 241 & Wye & -14.0 & 7.99 & 273 \\
\hline Evenlode & -13.6 & 8.00 & 253 & The Cut & -14.4 & 7.54 & 158 \\
\hline Cherwell & -14.6 & 7.93 & 252 & T-Hannington & -14.2 & 7.92 & 239 \\
\hline Ray & -14.5 & 7.81 & 242 & T-Swinford & -13.8 & 8.11 & 262 \\
\hline Ock & -13.4 & 8.03 & 288 & T-Wallingford & -14.6 & 7.94 & 263 \\
\hline Thame & -14.0 & 7.94 & 271 & T-Sonning & -14.0 & 7.92 & 242 \\
\hline Pang & -14.3 & 7.94 & 266 & T-Runnymede & -14.0 & 7.83 & 226 \\
\hline 16 Apr 2012 & & \multicolumn{6}{|c|}{16 Apr 2012 (contd.) } \\
\hline Coln & -12.7 & 8.08 & 248 & Kennet & -13.1 & 7.68 & 239 \\
\hline Cole & -14.1 & 8.05 & 242 & Enborne & -12.7 & 8.16 & 164 \\
\hline Leach & -13.4 & 7.78 & 249 & Loddon & -13.1 & 8.12 & 187 \\
\hline Windrush & -13.4 & 8.02 & 232 & Wye & -14.1 & 8.10 & 277 \\
\hline Evenlode & -12.9 & 7.95 & 201 & The Cut & -13.0 & 7.72 & 125 \\
\hline Cherwell & -13.7 & 7.89 & 260 & T-Hannington & -13.5 & 8.05 & 227 \\
\hline Ray & -17.1 & 7.72 & 247 & T-Swinford & -13.1 & 8.18 & 238 \\
\hline Ock & -12.6 & 8.37 & 268 & T-Wallingford & -13.3 & 8.04 & 239 \\
\hline Thame & -13.8 & 8.05 & 262 & T-Sonning & -12.8 & 8.38 & 233 \\
\hline Pang & -12.4 & 7.78 & 258 & T-Runnymede & -13.1 & 7.92 & 209 \\
\hline 23-24 Jul 2012 & & \multicolumn{6}{|c|}{ 23-24 Jul 2012 (contd.) } \\
\hline Coln & -13.4 & 7.93 & 258 & Kennet & -13.0 & 8.17 & 281 \\
\hline Cole & -13.8 & 7.96 & 298 & Enborne & -14.8 & 7.87 & 205 \\
\hline Leach & -13.9 & 7.88 & 282 & Loddon & -13.3 & 7.94 & 220 \\
\hline Windrush & -13.3 & 8.04 & 249 & Wye & -13.3 & 8.18 & 286 \\
\hline Evenlode & -13.6 & 7.80 & 279 & The Cut & -14.0 & 7.76 & 191 \\
\hline Cherwell & -14.4 & 7.78 & 251 & T-Hannington & -14.2 & 7.80 & 262 \\
\hline Ray & -14.7 & 7.49 & 316 & T-Swinford & -13.7 & 7.97 & 236 \\
\hline Ock & -13.9 & 7.99 & 302 & T-Wallingford & -13.6 & 8.00 & 286 \\
\hline Thame & -15.0 & 7.67 & 346 & T-Sonning & -14.1 & 8.05 & 286 \\
\hline Pang & -13.2 & 8.02 & 286 & T-Runnymede & -14.2 & 8.01 & 272 \\
\hline 22-23 Oct 2012 & & \multicolumn{6}{|c|}{ 22-23 Oct 2012 (contd.) } \\
\hline Coln & -13.7 & 7.95 & 270 & Kennet & -15.2 & 8.06 & 310 \\
\hline Cole & -15.4 & 7.92 & 314 & Enborne & -15.4 & 7.76 & 164 \\
\hline Leach & -13.7 & 8.05 & 285 & Loddon & -14.2 & 7.72 & 192 \\
\hline Windrush & -14.2 & 8.11 & 265 & Wye & -14.8 & 8.04 & 286 \\
\hline Evenlode & -14.4 & 8.02 & 281 & The Cut & -14.4 & 7.70 & 161 \\
\hline Cherwell & -14.7 & 7.96 & 297 & T-Hannington & -14.4 & 7.84 & 272 \\
\hline Ray & -15.3 & 7.48 & 155 & T-Swinford & -15.3 & 8.03 & 286 \\
\hline Ock & -16.2 & 7.89 & 346 & T-Wallingford & -15.8 & 7.94 & 272 \\
\hline Thame & -15.5 & 7.80 & 300 & T-Sonning & -13.6 & 7.96 & 256 \\
\hline Pang & -14.5 & 7.88 & 284 & T-Runnymede & -15.9 & 7.92 & 239 \\
\hline 14 Jan 2013 & & \multicolumn{6}{|c|}{14 Jan 2013 (contd.) } \\
\hline Coln & -13.2 & 8.04 & 267 & Kennet & -13.4 & 8.05 & 295 \\
\hline Cole & -14.5 & 8.12 & 316 & Enborne & -13.9 & 7.93 & 187 \\
\hline Leach & -13.4 & 8.07 & 280 & Loddon & -13.4 & 7.91 & 217 \\
\hline Windrush & -13.3 & 8.12 & 254 & Wye & -13.8 & 7.98 & 295 \\
\hline Evenlode & -14.1 & 8.08 & 256 & The Cut & -13.5 & 7.71 & 165 \\
\hline Cherwell & -14.3 & 8.03 & 249 & T-Hannington & -13.6 & 8.05 & 266 \\
\hline Ray & -15.0 & 7.83 & 301 & T-Swinford & -13.8 & 8.09 & 280 \\
\hline Ock & -14.2 & 8.12 & 314 & $\mathrm{~T}$-Wallingford & -13.8 & 8.03 & 285 \\
\hline Thame & -14.3 & 8.05 & 330 & T-Sonning & -13.9 & 8.08 & 285 \\
\hline Pang & -13.2 & 7.94 & 293 & T-Runnymede & -13.3 & 8.01 & 278 \\
\hline 15 Apr 2013 & & & & 15 Apr 2013 & & & \\
\hline Coln & -13.4 & 8.04 & 237 & Kennet & -14.3 & 8.14 & 255 \\
\hline Cole & -14.9 & 8.14 & 197 & Enborne & -14.6 & 7.91 & 157 \\
\hline Leach & -13.6 & 7.72 & 237 & Loddon & -13.8 & 7.73 & 169 \\
\hline Windrush & -13.7 & 8.03 & 221 & Wye & -14.3 & 8.05 & 263 \\
\hline Evenlode & -14.3 & 7.99 & 240 & The Cut & -14.0 & 7.76 & 145 \\
\hline Cherwell & -14.5 & 8.03 & 237 & T-Hannington & -14.0 & 7.96 & 238 \\
\hline Ray & -15.1 & 7.68 & 237 & T-Swinford & -14.5 & 8.10 & 254 \\
\hline Ock & -15.2 & 8.20 & 287 & $\mathrm{~T}$-Wallingford & -14.8 & 8.08 & 241 \\
\hline Thame & -14.9 & 7.88 & 281 & T-Sonning & -13.7 & 8.03 & 238 \\
\hline Pang & -13.8 & 8.00 & 252 & T-Runnymede & -14.6 & 7.96 & 226 \\
\hline
\end{tabular}

